Health and Safety Rescarch Division

1989 NEUTRON AND GAMMA PERSONNEL DOSIMETRY INTERCOMPARISON STUDY USING RADCAL SOURCES
C. S. Sims ${ }^{1}$
W. H. Casson ${ }^{1}$
H. Murakami ${ }^{2}$
J. C. $\mathrm{Liu}^{3}$
G. R. Patterson ${ }^{4}$

'Oak Ridge National Laboratory, P.O. Box 2008, Oak Ridge, TN 37831-6379.

${ }^{2}$ Dept. of Health Physics, JAERI, Tokai, Naka-Gun, Ibaraki 319-11, JAPAN.

${ }^{3} \mathrm{c}$. tanford Linear Accelerator Center, Bin 48, SLAC, P.O. Box 4349, Stanford, CA 94309.

${ }^{4}$ Deceased.

DATE PUBLISHED - OCTOBER 1990

Prepared for the

Physical and Technological Reserrch Division

Office of Health and Environmental Research

Budget Activity No.: KP0101000

Prepared by the

Oak Ridge National Laboratory

Oak Ridge, TN 37831-6285

operated by

MARTIN MARIETTA ENERGY SYSTEMS, INC.

for the

U.S. DEPARTMENT OF ENERGY

under contract DE-AC05-84OR21400 
TABLE OF CONTENTS

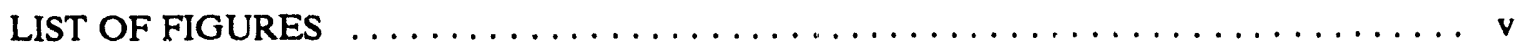

LIST OF TABLES $\ldots \ldots \ldots \ldots \ldots \ldots \ldots \ldots \ldots \ldots \ldots \ldots \ldots \ldots \ldots \ldots \ldots$

ACKNOWLEDGEMENTS $\ldots \ldots \ldots \ldots \ldots \ldots \ldots \ldots \ldots \ldots \ldots \ldots \ldots \ldots \ldots$ viii

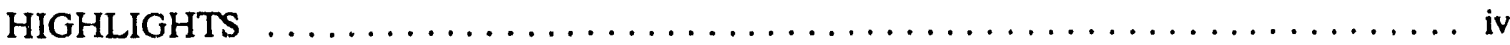

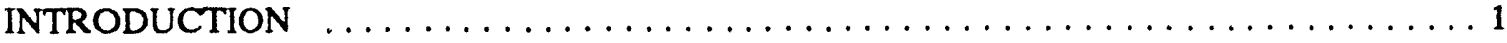

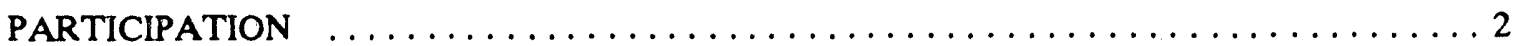

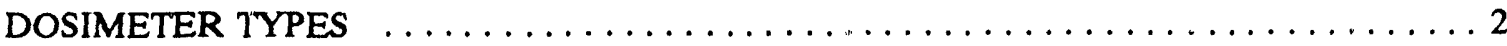

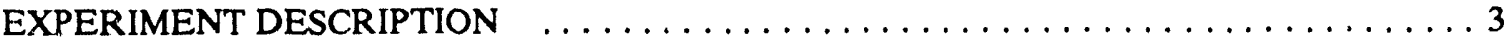

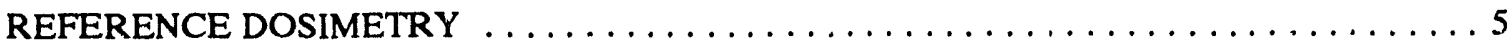

Neutron Dose Equivalent $\ldots \ldots \ldots \ldots \ldots \ldots \ldots \ldots \ldots \ldots \ldots \ldots$

Gamma Dose Equivalent $\ldots \ldots \ldots \ldots \ldots \ldots \ldots \ldots \ldots \ldots$

RESULTS AND ANALYSIS OF NEUTRON MEASUREMENTS $\ldots \ldots \ldots \ldots \ldots \ldots \ldots$

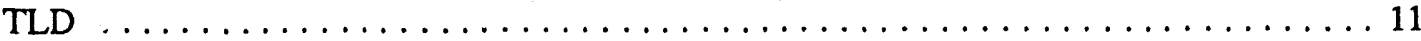

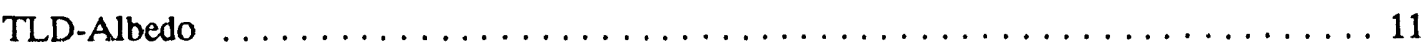

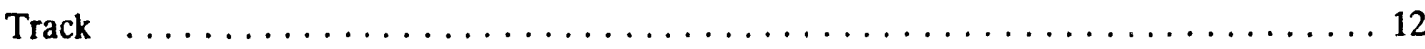

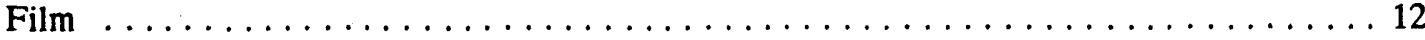

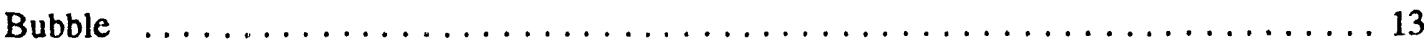

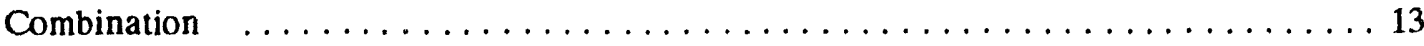

Composite of Neutron Results $\ldots \ldots \ldots \ldots \ldots \ldots \ldots \ldots \ldots \ldots \ldots \ldots$ 
RESULTS AND ANALYSIS OF GAMMA MEASUREMENTS $\ldots \ldots \ldots \ldots \ldots \ldots \ldots 14$

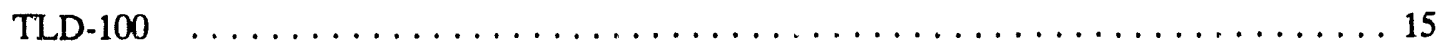

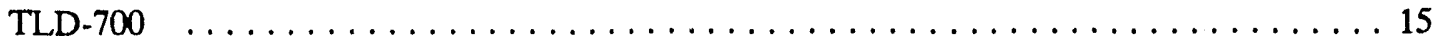

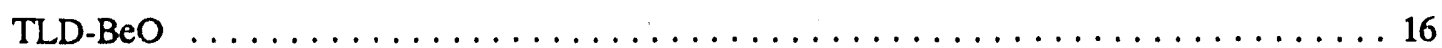

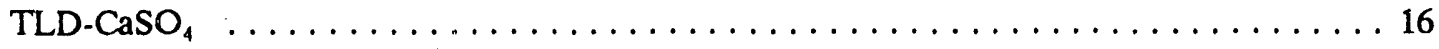

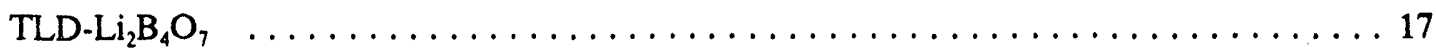

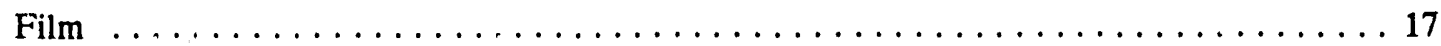

Composite of gamma results $\ldots \ldots \ldots \ldots \ldots \ldots \ldots \ldots \ldots \ldots \ldots \ldots \ldots \ldots$

RESULTS AND ANALYSIS OF THE TOTAL DOSE EQUIVALENT $\ldots \ldots \ldots \ldots \ldots 18$

RESULTS RELATIVE TO REGULATORY CRITERIA $\ldots \ldots \ldots \ldots \ldots \ldots \ldots \ldots 18$

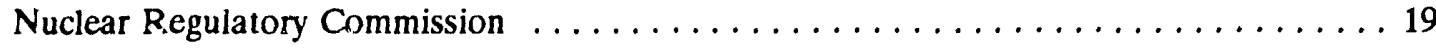

National Voluntary Laboratory Accreditation Program $\ldots \ldots \ldots \ldots \ldots \ldots$

ADDITIONAL PARTICIPANT-FURNISHED INFORMATION $\ldots \ldots \ldots \ldots \ldots \ldots \ldots 21$

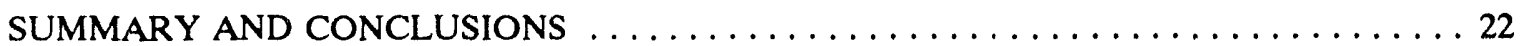

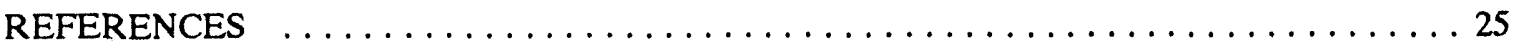




\section{LIST OF FIGURES}

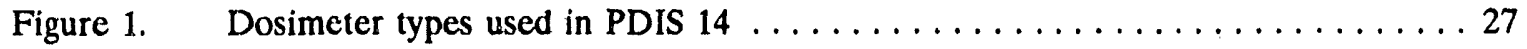

Figure 2. Experimental setup for cadmium-covered, $\mathrm{D}_{2} \mathrm{O}$-moderated ${ }^{252} \mathrm{Cf}$

irradiations (this particular photograph is for exposure number 3 ) $\ldots \ldots 28$

Figure 3. $\quad{ }^{137} \mathrm{Cs}$ irradiation configuration used as part of exposure number $2 \ldots \ldots \ldots$

Figure 4. Experimental arrangement for ${ }^{238} \mathrm{PuBe}$ exposures. $\ldots \ldots \ldots \ldots \ldots$

Figure 5. $\quad$ Average measured neutron dose equivalent presented by type of dosimeter $\ldots \ldots 31$

Figure 6. Average measured neutron dose equivalent in PDIS $14 \ldots \ldots \ldots \ldots$

Figure 7. Average measured gamma dose equivalent presented by type of dosimeter $\ldots \ldots 33$

Figure 8. Average measured gamma dose equivalent in PDIS $14 \ldots \ldots \ldots \ldots$

Figure 9. Avcrage measured total dose equivalent in PDIS $14 \ldots \ldots \ldots \ldots$ 


\section{LIST OF TABLES}

Table 1. Radiation exposure conditions for PDIS $14 \ldots \ldots \ldots \ldots \ldots \ldots \ldots \ldots$

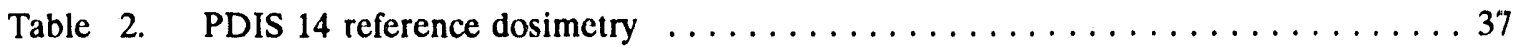

Table 3. Summary of reported neutron results for PDIS 14, exposure 1,

$15-\mathrm{cm} \mathrm{D} \mathrm{D}_{2} \mathrm{O}$-moderated ${ }^{252} \mathrm{Cf}, \mathrm{H}_{\mathrm{n}}=82\left(10^{-5}\right) \mathrm{Sv} \ldots \ldots \ldots \ldots \ldots \ldots \ldots \ldots \ldots$

Table 4. Summary of reported neutron results for PDIS 14, exposure 2,

$15-\mathrm{cm}$ polyethylene-moderated ${ }^{252} \mathrm{Cf}\left({ }^{137} \mathrm{Cs}\right.$ enhanced $), \mathrm{H}_{\mathrm{n}}=60\left(10^{-5}\right) \mathrm{Sv} \ldots \ldots \ldots 39$

Table 5. Summary of reported neutron results for PDIS 14, exposure 3,

$15-\mathrm{cm} \mathrm{D}_{2} \mathrm{O}$-moderated ${ }^{252} \mathrm{Cf}, 69^{\circ}$ rotation, perpendicular $\mathrm{H}_{\mathrm{n}}=258\left(10^{-5} \mathrm{~Sv} \ldots \ldots 40\right.$

Table 6. Summary of reported neutron results for PDIS 14, exposure 4, 15-cm

D2O-moderated ${ }^{252} \mathrm{Cf}$, without cadmium cover on sphere, $\mathrm{H}_{\mathrm{n}}=263\left(10^{-5}\right) \mathrm{Sv} \ldots \ldots 41$

Table 7. Summary of reported neutron results for PDIS 14 , exposure 5,

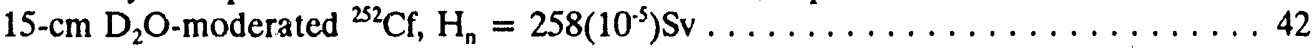

Table 8. Summary of reported neutron results for PDIS 14, exposure 6,

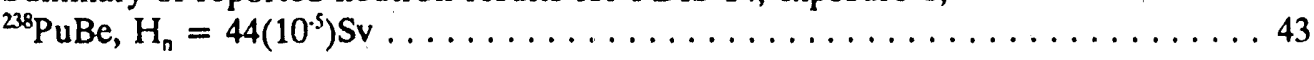

Table 9. Analysis of reported neutron results for exposure 1,

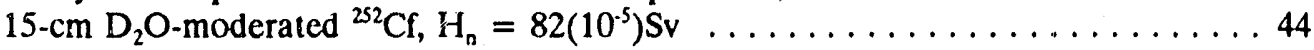

Table 10. Analysis of reported neutron results for exposure 2,

$15-\mathrm{cm}$ polyethylene moderated ${ }^{252} \mathrm{Cf}\left({ }^{137} \mathrm{Cs}\right.$ enhanced $), \mathrm{H}_{\mathrm{n}}=60\left(10^{-5}\right) \mathrm{Sv} \ldots \ldots \ldots 4$

Table 11. Analysis of reported neutron results for exposure 3,

15-cm $\mathrm{D}_{2} \mathrm{O}$-moderated ${ }^{252} \mathrm{Cf}, 60^{\circ}$ rotation, perpendicular $\mathrm{H}_{\mathrm{n}}=258\left(10^{-5}\right) \mathrm{Sv} \ldots \ldots 46$

Table 12. Analysis of reported neutron results for exposure 4, 15-cm $\mathrm{D}_{2} \mathrm{O}$-moderated

${ }^{252} \mathrm{Cf}$, without cadmium cover on sphere, $\mathrm{H}_{\mathrm{n}}=263\left(10^{-5}\right) \mathrm{Sv} \ldots \ldots \ldots \ldots \ldots 47$

Table 13. Analysis of reported neutron results for exposure 5,

15-cm $\mathrm{D}_{2} \mathrm{O}$-moderated ${ }^{252} \mathrm{Cf}, \mathrm{H}_{\mathrm{n}}=258\left(10^{-5}\right) \mathrm{Sv} \ldots \ldots \ldots \ldots \ldots \ldots \ldots$

Table 14. Analysis of reported neutron results for exposure 6,

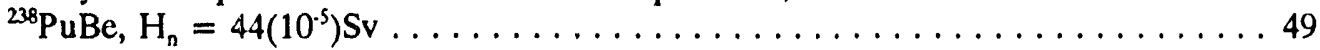

Table 15. Summaty of reported gamma results for PDIS 14, exposure 1,

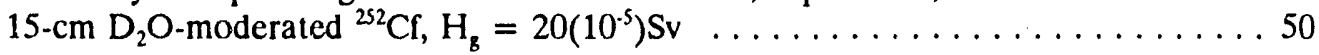

Table 16. Summary of reported gamma results for PDIS 14, exposure 2,

15 -cm polyethylene moderated ${ }^{252} \mathrm{Cf}\left({ }^{137} \mathrm{Cs}\right.$ enhanced $), \mathrm{H}_{\mathrm{g}}=185\left(10^{-5}\right) \mathrm{Sv} \ldots \ldots \ldots 51$ 
Table 17. Summary of reported gamma results for PDIS 14, exposure 3,

15-cm $\mathrm{D}_{2} \mathrm{O}$-moderated ${ }^{252} \mathrm{Cf}, 60^{\circ}$ rotation, perpendicular $\mathrm{H}_{\mathrm{g}}=52\left(10^{-5}\right) \mathrm{Sv} \ldots \ldots 52$

Table 18. Summary of reported gamma results for PDIS 14, exposure 4, 15-cm

$\mathrm{D}_{2} \mathrm{O}$-moderated ${ }^{252} \mathrm{Cf}$, without cadmium cover on sphere, $\mathrm{H}_{\mathrm{g}}=42\left(10^{-5}\right) \mathrm{Sv} \ldots \ldots 53$

Table 19. Summary of reported gamma results for PDIS 14, exposure 5,

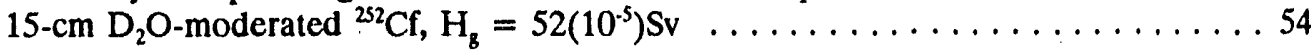

Table 20. Summary of reported gamma results for PDIS 14, exposure 6,

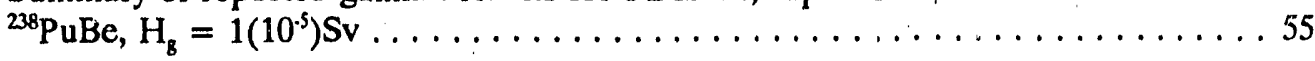

Table 21. Analysis of reported gamma results for exposure 1,

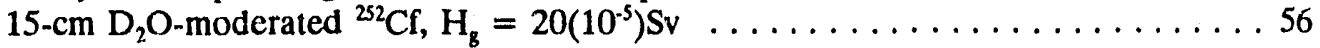

Table 22. Analysis of reported gamma results for exposure 2,

$15-\mathrm{cm}$ polyethylene moderated ${ }^{252} \mathrm{Cf},\left({ }^{137} \mathrm{Cs}\right.$ enhanced $), \mathrm{H}_{\mathrm{g}}=185\left(10^{-5}\right) \mathrm{Sv} \ldots \ldots 57$

Table 23. Analysis of reported gamma results for exposure 3,

$15-\mathrm{cm} \mathrm{D}_{2} \mathrm{O}$-moderated ${ }^{252} \mathrm{Cf}, 60^{\circ}$ rotation, perpendicular $\mathrm{H}_{\mathrm{B}}=52\left(10^{-5}\right) \mathrm{Sv} \ldots \ldots . \ldots 8$

Table 24. Analysis of reported gamma results for exposure $4,15-\mathrm{cm}$

$\mathrm{D}_{2} \mathrm{O}$-moderated ${ }^{252} \mathrm{Cf}$, without cadmium cover on sphere, $\mathrm{H}_{\mathrm{g}}=42\left(10^{-5}\right) \mathrm{Sv} \ldots \ldots 59$

Table 25. Analysis of reported gamma results for exposure 5,

$15-\mathrm{cm} \mathrm{D} \mathrm{D}_{2} \mathrm{O}$-moderated ${ }^{252} \mathrm{Cf}, \mathrm{H}_{\mathrm{g}}=52\left(10^{-5}\right) \mathrm{Sv} \ldots \ldots \ldots \ldots \ldots \ldots \ldots \ldots \ldots \ldots \ldots \ldots \ldots \ldots$

Table 26. Analysis of reported gamma results for exposure 6,

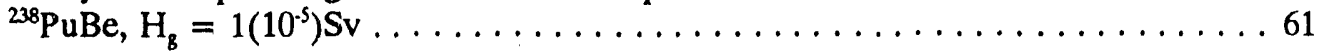

Table 27. Analysis of total dose equivalent for PDIS 14 exposures $\ldots \ldots \ldots \ldots \ldots \ldots 62$ 


\section{ACKNOWLEDGEMENTS}

The authors acknowledge the detailed work of Linda $R$. Pyles in preparation of this manuscript which contains so many tables and so much numerical analysis. We also gratefully acknowledge Dr. R. W. Wood, Director of the Physical and Technological Research Division of the U. S. Department of Energy, for funding the ongoing series of Personnel Dosimetry Intercomparison Studies. 


\title{
1989 NEUTRON AND GAMMA \\ PERSONNEL DOSIMETRY INTERCOMPARISON STUDY \\ USING RADCAL SOURCES
}

\author{
C. S. Sims ${ }^{1}$ \\ W. H. Casson ${ }^{1}$ \\ H. Murakami ${ }^{2}$ \\ J. C. Liu $^{3}$ \\ G. R. Patterson ${ }^{4}$
}

\section{HIGHLIGHTS}

The fourteenth Personnel Dosimetry Intercomparison Study (i.e., PDIS 14) was conducted during May $1-5,1989$. A total of 48 organizations ( 33 from the U.S. and 15 from abroad) participated in PDIS 14.

Participants submitted by mail a total of 1,302 neutron and gamma dosimeters for this mixed field study. The type of neutron dosimeter and the percentage of participants submitting that type are as follows: TLD-albedo (40\%), direct interaction TLD (22\%), track (20\%), film (7\%), combination (7\%), and bubble detectors (4\%). The type of gamma dosimeter and the percentage of participants submitting that type are as follows: TLD (84\%) and film (16\%).

Radiation sources used in the six PDIS 14 exposures included ${ }^{252} \mathrm{Cf}$ moderated by $15-\mathrm{cm} \mathrm{D}_{2} \mathrm{O},{ }^{252} \mathrm{Cf}$ moderated by $15-\mathrm{cm}$ polyethylene (gamma-enhanced with ${ }^{137} \mathrm{Cs}$ ), and ${ }^{238} \mathrm{PuBe}$. Neutron dose equivalents ranged from $0.44-2.63 \mathrm{mSv}$ and gamma doses ranged from $0.01-1.85 \mathrm{mSv}$.

One ${ }^{252} \mathrm{Cf}\left(\mathrm{D}_{2} \mathrm{O}\right)$ exposure was performed at a $60^{\circ}$ angle of incidence (most performance tests are at perpendicular incidence). The average neutron dosimeter response for this exposure was $70 \%$ of that at normal incidence. The average gamma dosimeter response was $96 \%$ of that at normal incidence.

A total of $70 \%$ of indivioual reported neutron dosimeter measurements were within ${ }_{ \pm} 50 \%$ of reference values. If the $0.01 \mathrm{mSv}$ data are omitted, approximately $90 \%$ of the individual reported gamma measurements were within $\pm 50 \%$ of reference values.

\footnotetext{
'Oak Ridge National Laboratory, P.O. Box 2008, Oak Ridge, TN 37831-6379. ${ }^{2}$ Dept. of Health Physics, JAERI, Tokai, Naka-Gun, Ibaraki 319-11, JAPAN. ${ }^{3}$ Stanford Linear Accelerator Center, Bin 48, SLAC, P. O. Box 4349, Stanford, CA 94309. ${ }^{4}$ Deceased.
} 


\section{INTRODUCTION}

The fourteenth in a series of annual neutron and gamma Personnel Dosimetry Intercomparison Studies (i.e., PDIS 14$)^{1-4}$ was conducted at the Oak Ridge National Laboratory (ORNL) during May 1-5, 1989. The Dosimetry Applications Research (DOSAR) Group staff conducted PDIS 14 using ${ }^{238} \mathrm{PuBe}$ and ${ }^{252} \mathrm{Cf}$ (with two different moderators) neutron sources and a ${ }^{137} \mathrm{Cs}$ source available in the new Radiation Calibration Laboratory (RADCAL) $)^{5}$. The PDIS have traditionally been conducted using the Health Physics Research Reactor (HPRR) ${ }^{6-7}$ as the radiation source. However, all research reactors at ORNL (including the HPRR) were shut down by order of the Department of Energy on March 26, 1987. Because the reactor had not been restarted at the scheduled time of PDIS 14 , the study was conducted entirely at RADCAL. Depending on HPRR availability, future PDIS may involve irradiations at RADCAL as well as the HPRR.

In general, ORNL intercomparisons are designed to allow participants to test their dosimetry systems under various conditions and to compare their results with those of others making measurements under ideritical conditions and with reference dosimetry. The PDIS are intended to provide more comprehensive tests of the neutron-gamma abilities of dosimetrists and their dosimetry systems than are the National Voluntary Laboratory Accreditation Program (NVLAP) ${ }^{8}$ and the Department of Energy Laboratory Accreditation Program (DOELAP)' ${ }^{9}$ It is hoped that, because of the variety of exposure conditions, the PDIS will provide a learning experience for all participants. In particular, various PDIS 14 test conditions mocked up typical NVLAP and DOELAP exposures, repeated those exposures with different scattering conditions, caused participants to have to deal with nonperpendicular incidence of radiation, used extremes of neutron-to-gamma ratios, provided a very hard neutron energy spectrum, and provided a spectrum for which it is doubtful that anv participants had previously calibrated. 
In PDIS 14, personnel neutron and gamma dosimeters were mailed by participants to ORNL. The dosimeters were exposed at RADCAL to neutron dose equivalents in the $0.44-2.63 \mathrm{mSv}(44-263$ mrem) range and gamma dose equivalents in the 0.01-1.85 $\mathrm{mSv}$ (1-185 mrem) range. Following exposure, the dosimeters were returned to the participants for evaluation. This document is a summary and analysis of results reported to the DOSAR staff by PDIS 14 participants.

\section{PARTICIPATION}

A total of 48 organizations, 33 from the United States and 15 from abroad, participated in this PDIS. Of the 48 participating organizations, 41 reported their results to the DOSAR staff. These 41 included government laboratories (14), nuclear utilities (12), dosimeter vendors (6), universities (4), medical facilities (2), and an industrial organization (1). To ensure anonymity, they are identified by numbers in the data summary tables and discussion.

\section{DOSIMETER TYPES}

The 48 participating organizations submitted 62 sets of 21 dosimeters each (some submitted more than one badge type). A set of 21 dosimeters consisted of 3 background (or control) dosimeters and 3 dosimeters for each of the 6 exposures. A total of 1,302 dosimeters were handled by the DOSAR staff: 186 were controls and 1,116 were actually exposed to radiation. Measured neucron results were reported for 722 of the exposed dosimeters and measured gamma results were reported for 755 of the exposed dosimeters.

Figure 1 shows the collection of dosimeters submitted by PDIS 14 participants. In the figure, 59 of the 62 dosimeters shown are divided into groups by type of organization submitting that cosimeter: Department of Energy (DOE) labs, nuclear utilities, vendors and others, universities, and outside USA. Three others, identified as bubble detectors ${ }^{10-11}$, are shown separately because this is the first PDIS in which this new type of personnel neutron dosimeter has been used. 
As can be seen from Figure 1, relatively few of the badge designs are the same. However, the neutron detection mechanisms can be divided into six categories: direct interaction thermoluminescent dosimeters (TLD), TLD albedo, recoil track, film, combination, and bubble detectors (also called superheated drop). The TLD albedo and the direct interaction TLD, which have traditionally been the most popular types of neutron dosimeters used in the ORNL intercomparisons, were used by $40 \%$ and $22 \%$, respectively, of the organizations reporting results. These TLD systems almost exclusively used the traditional Panasonic $\left({ }^{6} \mathrm{Li}_{2}{ }^{10} \mathrm{~B}_{4} \mathrm{O}_{7}\right)$ or Harshaw $\left({ }^{6} \mathrm{LiF}\right)$ materials as the primary neutron detection elements. Recoil track dosimeters (mainly CR-39 material) were used by $20 \%$ of the reporting organizations, film dosimeters (Kodak NTÁ type) were used by 7\%, combination dosimeters (two TLD albedo-track dosimeters and a TLD albedo-bubble detector) were used by 7\%, and bubble detectors were used by $4 \%$ of those reporting neutron results. Readily accessible literature contains excellent descriptions and discussions of the various types of neutron dosimeters. ${ }^{12-14}$

Concerning reported gamma results, $84 \%$ of the reporting organizations used TLD systems and $16 \%$ used film (primarily Kodak type 2, but one used Fuji type G-3). About 54\% of the TLD badges used $\mathrm{CaSO}_{4}$ alone or in combination with $\mathrm{Li}_{2} \mathrm{~B}_{4} \mathrm{O}_{7}, 35 \%$ used ${ }^{7} \mathrm{LiF}$ (TLD-700) material, $8 \%$ used natural $\mathrm{LiF}$ (TLD-100), and about 3\% (one organization) used a TLD containing $\mathrm{BeO}$. Information concerning gamma dosimeter types is abundant in the literature. ${ }^{15-17}$

\section{EXPERIMENT DESCRIPTION}

Six different types of radiation exposures were conducted at RADCAL during PDIS 14. These six are summarized in Table 1. The so-called "9/3-inch ration was measured using a tare ${ }^{10} \mathrm{BF}_{3}$ tube inside a $23-\mathrm{cm}(9 \mathrm{inch})$ diameter polyethylene sphere and inside a $7.6-\mathrm{cm}(3 \mathrm{inch})$ diameter polycthylene sphere covered with a cadmium sheet. The average neutron energies were taken from the available literature relative to the various sources except for exposure number 2 where we determined the value using Bonner sphere measurements. ${ }^{18}$ All the information in Table 1 was provided to the participants prior to their evaluation of the exposures. 
Exposures $1,3,4$, and 5 involved radiation from ${ }^{252} \mathrm{Cf}$ moderated by $15-\mathrm{cm}$ of $\mathrm{D}_{2} \mathrm{O}$. Figure 2 is a photograph which clearly shows the cadmium covered $\mathrm{D}_{2} \mathrm{O}$ sphere and the dosimeters mounted on two standard $40 \times 40 \times 15-\mathrm{cm}$ Lucite slab phantoms in an irradiation setup typical of these exposures. Exposure 2 involved ${ }^{252} \mathrm{Cf}$ radiation moderated by a $15-\mathrm{cm}$ polyethylene sphere and enhanced by gammas from a ${ }^{137} \mathrm{Cs}$ source. That neutron exposure setup was similar to that shown in Figure 2 and the gamma portion of exposure number 2 was accomplished with the irradiator as shown in Figure 3. Exposure 6 invoived radiation from a ${ }^{238} \mathrm{PuBe}$ source. Figure 4 shows a typical irradiation setup for this portion of PDIS 14 .

The reader is advised that RADCAL was in the process of becoming operational when PDIS 14 was conducted. The makeshift phantom stands, evident in Figures 2-4, have since been replaced by custom designed, track mounted stands. More professional precision aligned mounts were used during the conduct of PDIS 15 in 1990.

The six exposures were designed to provide the participating dosimetrists a challenge, as well as to allow them to collect information which should prove useful in evaluating overall dosimeter performance and in preparing for broadened performance testing should that become required by NVLAP and/or DOELAP. Exposures 1 and 5 were typical of what dosimeters traditionally see in current NVLAP and DOELAP performance tests, but with varied scattering components. Exposure 3 was designed to investigate angular response and provide participants with some minimum information about their dosimeter's capabilities at nonperpendicular angles of incidence. Exposures 2 and 6 used neutron energy spectra significantly different from what is traditionally seen in performance tests and provided dosimetrists additional information concerning response to a hard (exposure 6) spectrum with a high neutron-to-gamma ratio and a soft (exposure 2) spectum with a relatively low neutron-to-gamma ratio. Results of exposure 4 should convince many dosimetrists of the importance of properly treating their dosimeter's response to thermal neutrons. 


\section{REFERENCE DOSIMETRY}

Reference neutron and gamma dose equivalents for PDIS 14 are summarized in Table 2 and details are presented in the following text.

\section{Neutron Duse Equivalent}

Neutron dose equivalents ranged from $0.44 \mathrm{mSv}$ (44 mrem) in exposure 6 to $2.63 \mathrm{mSv}$ (263 mrem) in exposure 4. The scatter adjusted geutron reference value for exposure 2 was deitermined using Bonner sphere measurements. For all other exposures, the reference value for the primary beam was determined by using the National Institute of Standards and Technology (NIST) calibration of the sources and applying fluence-to-dose equivalent conversion factors. The conversion factors used were those advocated by the International Commission on Radiological Protection in Publication Number 21 (i.e., ICRP 21) ${ }^{19}$. Scattered neution components were calculated for all exposures using NIST-recommended formulas ${ }^{2021}$. The remainder of this section is an amplification of the information presented above.

${ }^{238} \mathrm{PuBe}$ Irradiation (exposure 6). The ${ }^{228} \mathrm{PuBe}$ source (serial number MRC Pu8Be-496) was used in exposure 6. The Monsanto Corporation determined the n/utron emission rate to be $2.4\left(10^{7}\right) \mathrm{s}^{-1}$ on $3 / 22 / 82$. The method of determination was by the use of long counter results compared against NISTcalibrated ${ }^{268} \mathrm{PuBe}$ standard sources. The activity at the time of PDIS 14 was determined by use of the 87.4-year half-life. Using this activity, the neutron fluence rate at $1.0-\mathrm{m}$ was calculated to be $180 \mathrm{~cm}^{-2} \mathrm{~s}^{-1}$. By use of a published ${ }^{238} \mathrm{PuBe}$ neutron energy spectrum $\mathrm{m}^{22}$ and familiar techniques described elsewhere ${ }^{3}$, we determined that the spectrum averaged fluence-to-ICRP 21 dose equivalent conversion factor is $370 \mathrm{pSv}-\mathrm{cm}^{2}\left(3.7\left(10^{-5}\right)\right.$ mrem- $\left.\mathrm{cm}^{2}\right)$. Combined with the fluence rate, this yields a dose rate of $0.24 \mathrm{mSv} / \mathrm{h}$ (i.e., $24 \mathrm{mrem} / \mathrm{h}$ ) at $1.0-\mathrm{m}$. The duration of the PDIS exposure was $1.75-\mathrm{h}$ and resulted in a dose equivalent of $0.42 \mathrm{mSv}$ ( $42 \mathrm{mrem}$ ) from the primary beam. The $5 \%$ scattering contritution 
to the total dose equivalent was calculated following Eisenhauer's documented techniques ${ }^{21}$. The ${ }^{238} \mathrm{PuBe}$ irradiation was done $1.38-\mathrm{m}$ above the concrete floor in the low scatter alumin 2 in room of building 7712 adjacent tc PADCAL. Consequently, only single surface scatter from the concrete floor was considered in the calculation (walls and ceiling were not included). The appropriate room scatter equation is

$$
R=2 a b(\cos g)(r / h)^{2}=0.04
$$

where $R=$ relative dose equivalent response $^{-}$scattered and primary beam neutrons

$\mathrm{a}=$ albedo of reflecting surface (taken to be 0.54$)^{20-21}$

$b=$ combined anisotropy and specirai iesponse factor (taken to be 0.37$)^{20.21}$

$\cos y=$ cosine of the specular angle $y(0.94$ in this case)

$r=$ source-to-dosimeter distance $(1-\mathrm{m})$

$\mathrm{h}=$ source-to-image source distance $(2.936-\mathrm{m})$

The air scatter for this hard source ${ }^{21}$ is approximately $1 \% / \mathrm{m}$. At $1 \mathrm{~m}$, this $1 \%$ is added to the $4 \%$ room scatter for the total of $5 \%$ mentioned above and shown in Table 2.

$\underline{D_{2}} \mathrm{O}$ Moderated ${ }^{252} \mathrm{Cf}$ Irradiations (exposL. es 1, 3,4 and 5). The ${ }^{252} \mathrm{Cf}$ source designated NSD-107 was used in exposures $1,3,4$ and 5 . The source emission rate was determined by NIST to be $7.63\left(10^{9}\right) \mathrm{s}^{-1}$ on $4 / 30 / 87$. Activity at the time of PDIS 14 was determined by use of the $2.64-y$ half-life to be $4.51\left(10^{9}\right) \mathrm{s}^{-1}$. The spectrum averaged fluence-to-dos 2 equivalent conversion factor was taken to be 90.8 pSv-cm $\left(9.08\left(10^{-6}\right) \mathrm{mrcm}-\mathrm{cm}^{2}\right){ }^{2-24}$ In general, the neutron dose equivalent due to the primary beam from the $\mathrm{D}_{2} \mathrm{O}$-moderated, caúnium-covered, ${ }^{252} \mathrm{Cf}$ source is given by the expression ${ }^{25}$

$$
\mathrm{H}_{\text {npo }}=\operatorname{NCt}(3600)(0.885) / 4 \pi \mathrm{r}^{2}
$$

where $\mathrm{N}=$ neutron emission rate, $\mathrm{s}^{-1}$

$\mathrm{C}=$ conversion factor, $\mathrm{mrem}-\mathrm{cm}^{2}$

$t=$ exposure time, $h$

$\mathrm{r}=$ source-to-phantom distance, $\mathrm{cm}$

$0.885=$ factor to allow for loss of neutrons below cadmium cutoff. 
Exposure 1 was performed with the phantoms at $1.5 \mathrm{~m}$ from the source. Using Eqn. (2), the exposure time of 9 minutes resulted in $\mathrm{H}_{\mathrm{npo}}=69\left(10^{-5}\right) \mathrm{Sv}$ (i.e., $69 \mathrm{mrem}$ ) as recorded in Table 2. The RADCAL neutron room is essentially a rectangular, concrete-enclosed room. Following Eisenhauer ${ }^{21}$, the appropriate room scattering equation is

$$
R=4.5 b\left(r / r_{c}\right)^{2}
$$

where $r_{c}$ is defined by the equation

$$
4 \pi r_{c}^{2}=\sum A_{i}
$$

and

$R=$ relative dose equivalent response to scattered and prinary beam neutrons

$\mathrm{b}=$ combined anisotropy and spectral response factor (taken to be 0.49$)^{20.21}$

$r_{c}=$ radius of spherical cavity which has the same surface area as the actual calibration room (calculated to be $5.5 \mathrm{~m}$ )

$A_{i}=$ area of the ith surface of the calibration roum, $\mathrm{m}^{2}$

$r=$ Jurie-to-detector distance, $\mathrm{m}$

For $r=1.5 \mathrm{~m}, \mathrm{R}=0.164$. Air scatter for this moderated source ${ }^{21}$ is taken to be $1.5 \% / \mathrm{m}$. At $1.5 \mathrm{~m}$, this $2.25 \%$ added to the $16.4 \%$ room scatter results in the $19 \%$ total scatter component for exposure 1 recorded in Table 2. If future attempts are made to refine the calculation of $R$, it should be recognized that the shielding in the RADCAL neutron room ceiling is significantly less the:- that in the walls and floor. Detaiied analysis of that could lead to a slight modification of the $r_{c}$ value used above.

Exposure 5 was performed with the phantoms at $0.75 \mathrm{~m}$ from the source. Using this information in Eqn. (2), the exposure time of 8 minutes resulted in $H_{n p o}=246\left(10^{-5}\right)$ Sv (i.e., $246 \mathrm{mrem}$ ) as recorded in Table 2. Using $r=0.75 \mathrm{~m}$, the room scatter was calculated via Eqn. (3) to be about $4.1 \%$. At $1.5 \% / \mathrm{m}$, the air scatter at $0.75 \mathrm{~m}$ was determined to be $1.1 \%$. Consequently, the total scatter component reported in Table 2 is $5 \%$. 
Exposure 3 was identical to exposure 5 except the phantom was rotated $60^{\circ}$ clockwise about the vertical centerline of the surface of the phantom which was kept at $0.75 \mathrm{~m}$ from the source. The dosimeters were mounted along the vertical centerline to assure that they would all be exposed equidistant from the source. The dose equivalent reported in Table 2 at this $60^{\circ}$ angle is that at perpendicular incidence. The effective dose equivalent (which is legally used in limiting personnel exposure) actually decreases as a function of angle away from perpendicular, but the appropriate dosimetric behavior has not yet been approved by authoritative bodies. The results of this study will, however, allow participants to determine their dosimeter's relative response at $60^{\circ}$.

Exposure 4 was identical to exposure 5 except the thin cadmium shell was removed from the $\mathrm{D}_{2} \mathrm{O}$ filled steel sphere. As previously stated, $88.5 \%$ of the $\mathrm{D}_{2} \mathrm{O}$-moderated ${ }^{252} \mathrm{Cf}$ neutrons are above the cadmium cutoff energy. Therefore, removing the cadmium shell increases the fluence by $11.5 \%$. To determine the associated increase in dose equivalent, equation 2 may be used with the ICRP 21 fluence-to-dose equivalent conversion factor appropriate for thermal neutrons: $10.7 \mathrm{pSv}-\mathrm{cm}^{2}$ (i.e., $\left.1.07 \times 10^{-6} \mathrm{mrem}-\mathrm{cm}^{2}\right)$. Using values already presented, the ratio of the dose equivalent from the primary beam for the "without cadmium" exposure to that with cadmium is:

$$
\frac{\mathrm{H}(w 0)}{\mathrm{H}(w)}=\frac{0.885(9.08)+0.115(1.07)}{0.885(9.08)}=1.015
$$

This means that removing the cadmium cover increases the neutron fluence by $11.5 \%$, but only increases the dose equivalent by $1.5 \%$. The scattered component is assumed to be the same as tha! reported for exposure 5 and the results are tabulated in Table 2.

Polyethylene Moderated ${ }^{252} \mathrm{Cf}$ Irradiation (exposure 2). The ${ }^{252} \mathrm{Cf}$ source designated NSD-87 was used in exposure 2. The source emission rate was determined by NIST to be $2.51\left(10^{9}\right) \mathrm{s}^{-1}$ on $5 / 6 / 87$. Activity at the time of PDIS 14 was determined by use of the $2.64-y$ ha' f-life. The NSD-87 source was inserted in a $15-\mathrm{cm}$ diameter polyethylene sphere and positioned such that the source centerline was 
$1.83-\mathrm{m}$ above the floor. Keference dosimetry for this irradiation was determined by measurements made with a Bonner multisphere spectrometer ${ }^{26}$. The measurements were a joint effort between Dr. Ferenc Hajnal of the Environmental Measurements Laboratory and the DOSAR staff. The dose equivalent rate at $1-\mathrm{m}$ from the source was determined to be $1.8 \mathrm{mSv} / \mathrm{h}(180 \mathrm{mrem} / \mathrm{h})$ at the time of PDIS $14^{27}$. The 20 minute irradiation resulted in a total dose equivalent of $0.60 \mathrm{mSv}(60 \mathrm{mrem})$. Details associated with the measurement and analysis are being published elsewhere ${ }^{28}$.

The measured results considered above included room and air scatter. To calculate the scatter contribution to the total, a simplifying assumption was made since values for needed parameters in the scattering equations were not available for this unusual polyethylene moderated source. Since the average energy for this source-moderator combination was found by the multisphere measurements to be intermediate between bare and $\mathrm{D}_{2} \mathrm{O}$-moderated ${ }^{252} \mathrm{Cf}$, it was assumed that the scattering contribution would also be intermediate between them. At 1-m, the total scatiering from the $\mathrm{D}_{2} \mathrm{O}$ moderated ${ }^{252} \mathrm{Cr}$ source in RADCAL was calculated by techniques used above to be $9 \%$. For bare ${ }^{252} \mathrm{Cf}$, it was calculated to be $7 \%$. It was, therefore, assumed that the scattering for this source at $1-\mathrm{m}$ is $8 \%$ as indicated in Table 2.

\section{Gamma Dose Equivalent}

As seen in Table 2, gamma dose equivalents in PDIS 14 ranged from 0.01-1.85 mSv (1-185 mrem). Neutron-to-gamma dose equivalent ratios varied from 0.32 in exposure 2 to 44.0 in exposure 6.

Reference gamma dose equivalents for all six mixed-field exposures were measured with a Phillips No. 18509 Geiger-Mueller (GM) counter $^{29}$ mounted directly on a Lucite slab phantom. The GM counter is $1.6 \mathrm{~cm}$ long and $0.48 \mathrm{~cm}$ in diameter. It has been shown that the neutron dose response 
of this counter is $<0.5 \%$ of the gamma dose response. The GM counter was calibrated with the ${ }^{137} \mathrm{Cs}$ irradiator shown in Figure 3.

The gamma dose equivalent rate associated with the ${ }^{137} \mathrm{Cs}$ irradiator is traceable to NIST. The reference gamma dose equivalent for the ${ }^{137} \mathrm{Cs}$-enhanced portion of exposure 2 was determined from the exposure time and the NIST-related dose equivalent rate.

\section{RESULTS AND ANALYSIS OF NEUTRON MEASUREMENTS}

Tables 3-8 summarize reported neutron results for each exposure. Irradiation data given in these tables include exposure number, source, and reference neutron dose equivalent in the ICRP 21 convention. Results shown for each participant consist of numbered organization identification, neutron dosimeter type, reported dose equivalents for each mounted badge, and the average of all reported results. Neutron dosimeter performance characteristics described below were derived from the basic data presented in these tables.

Analyses of reported neutron measurements are presented in Tables 9-14 for the composite of all results, for the subset of results which were less than three times the reference value, and for each of the six neutron dosimeter types used in this study. In these tables, data given for each exposure include the reference neut:on dose equivalent, the number of participants reporting results, the range of normalized (measured divided by reference) results, and the mean and one standard deviation about the mean of the normalized measurements. Figures 5 and 6 graphically present some of the data contained in Tables 9-14. The data are discussed below under headings associated with each neutron dosimeter type used in the study as well as the composite of all neutron results. 
TLD

About $22 \%$ of the participants in PDIS 14 measured neutrons using direct interaction TLD's. The majority of these were Panasonic type UD-802. Notice that these are not TLD albedo dosimeters which are considered below. The average results plotted in Figure 5 show that TLD's overresponded by about $30-50 \%$ for the ${ }^{252} \mathrm{Cf}\left(\mathrm{D}_{2} \mathrm{O}\right)$ exposures (i.e., 1,4 , and 5) and that the presence or absencc of the cadmium shell made surprisingly little difference (it caused an increase of about $10 \%$ on the average). The best TLD results were for the PuBe cxposure where the average overresponse was only $11 \%$. The poorest accuracy was for the polyethylene moderated ${ }^{252} \mathrm{Cf}$ exposure (i.e., number 2 ) where the average overresponse was more than a factor of 2 . In general, these types of dosimeters do a good job when the calibration field is the same as the measured field, but many in current use have limited capability to distinguish a variety of experimental conditions. These TLD's exhibited a relatively moderate angular dependence in that the dose equivalent at $60^{\circ}$ incidence was about $66 \%$ of that at perpendicular incidence (compare exposures 3 and 5).

\section{TLD-albedo}

About $40 \%$ of PDIS 14 participants used TLD albedo dosimeters to determine the neutron dose equivalent. From Figure 5, it is seen that the average resuits overestimate the actual dose equivalent from $15-57 \%$ for the 5 exposures made at perpendicular incidence. The average TLD albedo dosimeter, like the direct interaction TLD's, exhibited a moderate angular dependence. The dose equivalent at $60^{\circ}$ incidence was, on the average, $62 \%$ of thar at perpendicular incidence. The overall response of the TLD albedo dosimeters wa" remarkably close to, but perhaps slightly better than, that of direct interaction TLD's for all exposures except number 2, the polyethylene moderated irradiation. The albedo results were significantly better (overresponse by a factor of 1.57 as opposed to a factor of 2.16) than those for direct interaction TLD's for that exposure. Like direct interaction TLD's, the TLD albedo dosimeters' response to exposure 4 (the no-cadmium exposure) was only about $10 \%$ larger than the response to exposure 5. We at DOSAR were concerned that the $11 \%$ increase in 
thermal neutron fluence in exposure 4 over that in exposure 5 would lead participants using TLD and TLD albedo systems to significantly overrespond due to their high sensitivity to low energy neutrons. On the average, PDIS 14 results show that situation did not occur.

Track

Examination of Figure 5 indicates track dosimeter results were generally the least accurate of any of the neutron dosimeter types used in PDIS 14. They overresponded in every case and the overresponse increased monotonically with increasing spectrum hardness. The results (Tables 9-14) also show that the track measurements have the largest standard deviations of any of the neutron dosimeter types. The reader is reminded that these results are composite ones for all the track dosimeters used in PDIS 14 and that, as for other dosimeter types, some individual participants reported very good results using track dosimeters. Exposures 3 and 5 were identical ${ }^{252} \mathrm{Cf}\left(\mathrm{D}_{2} \mathrm{O}\right)$ exposures except 3 was done at a $60^{\circ}$ angle of incidence. The track dosimeters exhibited a strong angular dependence. The average $60^{\circ}$ incidence response was $54 \%(1.06 / 1.95)$ of that at perpendicular. The effect of the removal of the cadmium shell can be determined by comparing results of exposure 4 (without cadmium) to those of exposure 5. Average track results were generally about $10 \%$ higher for exposure 5 than for 4 , but the numbers are well within one standard deviation of each other. Since track dosimeters don't measure thermal neutrons, the numbers were expected to essentially be the same.

Film

About 7\% of PDIS 14 participants used film (all Kodak NTA) to measure neutron dose equivalents. Examination of the results plotted in Figure 5 reveals that the overall film resuits were the most accurate of all dosimeter types for the two hardest spectra in the study (i.e., exposures 2 and 6). The mean measured results nermalized to reference values were $0.96 \pm 0.48$ and $1.08 \pm 0.20$, respectively, for these exposures. Film, being a threshold-type dosimeter, is much better suited for the measurement of hard spectra than for soft. In addition, those participants who used film calibrated 
their dosimeters with either $\mathrm{PuBe}$ or $\mathrm{AmBe}$. Had they calibrated with ${ }^{252} \mathrm{Cf}\left(\mathrm{D}_{2} \mathrm{O}\right)$, they probably would not have overresponded by a factor of 1.6-2.2 like they did for exposures 1,4 , and 5. Like track dosimeters, film exhibited a strong angular dependence: the average response at $60^{\circ}$ (exposure 3 ) was only $43 \%$ of that at perpendicular incidence (exposure 5). Again like track dosimeters, the presence or absence of the cadmium shell (exposures 5 and 4) made little difference (results were $12 \%$ higher with the shell in place, but they were well within one standard deviation).

\section{Bubble}

Two participant groups (numbers 2 and 21) used bubble detectors to measure neuiron dose equivalent. A third group (number 26) used a bubble detector-TL.D albedo combination, but their results are included in the combination dosimeter category. The bubble detectors tested were of different types: the one used by group number 2 was a direct reading type (moveable plunger pointed to dose equivalent value) and the other was a "count the bubbles" type. The measured results displayed very low standard deviations for all six exposures. As seen in Figure 5, the mean measured results were generally low by about $30 \%$. A calibration factor change could easily correct this since the rcsults were relatively consistent across the range of spectra used in PDIS 14. The results were, however, somewhat more accurate for harder spectra than for soft.

\section{Combination}

Three participant groups $(17,26$, and 41B) used combination dosimeters in this study. Combination units are designed to use the best capabilities of two types of dosimeters in covering a wide range of neutron energy spectra. It is, therefore, not surprising that, on average, the combination dosimeters were the most accurate neutron dosimeters for PDIS 14 exposures 1-5 (see Figure 5). The mean measured dose equivalents were within $20 \%$ of reference values and the standard deviations were low. The poor results (average overresponse by a factor of 2.5) for exposure 6 are attributed to one TLD albedo-track reading which was high by a factor of 5.23. At PuBe energies, such combination units 
typically rely on the track portion of the dosimeter. At low doses like that in ex ind $_{1}$ osure 6 (i.e., $44\left(10^{-5}\right)$ Sv), generally available track dosimeters have not performed well in hard spectra ${ }^{30}$.

\section{Composite of Neutron Results}

A subset of all neutron reported results is presenced in Figure 6 for each of the PDIS 14 exposures. The subset eliminates all results (about $7 \%$ of those reported) which were greater than three times the reference values. Overall, the most accurate measurements were made for exposure 6 (PuBe). This exposure had the hardest neutron energy spectrum and, interestingly enough, the lowest dose equivalent $\left(44 \times 10^{-5} \mathrm{~Sv}\right)$. Exposure 4 , with $263\left(10^{-5}\right) \mathrm{Sv}$, had the largest dose equivalent, but the measurements were the least accurate overall. This exposure had the softest spectrum. Harder spectra led to more accurate measurements. The average response to ${ }^{252} \mathrm{Cf}\left(\mathrm{D}_{2} \mathrm{O}\right)$ neutrons at $60^{\circ}$ incidence was $70 \%$ of that at perpendicular incidence (the realer is reminded that this is a subset of all results). The average response to ${ }^{252} \mathrm{Cr}\left(\mathrm{D}_{2} \mathrm{O}\right)$ without the cadmium sheet was greater than that for the "with cadmium" exposure by $15 \%$.

\section{RESULTS AND ANALYSIS OF GAMMA MEASUREMENTS}

Gamma results reported for the six mixed radiation fields encountered in PDIS 14 are summarized in Tables 15-20. Data presented in these tables include exposure number and reference gamma dose equivalent. Results shown for each participant include the organization identification number, gamma dosimeter type, gamma dose equivalent for each mounted badge, and the average of all reported results. Gamma dosimeter performance characteristics described below are based on the data presented in these tables. Figures 7 and 8 graphically preseni some of the data contained in Tables 21-26. 
Analyses of reported gamma measurements are presented in Tables 21-26 for the composite of all results and for the basic dosimeter typus used in PDIS 14. Data shown in each table include the reference gamma dose equivalent, the number of participants reporting results, the range of normalized results, and the mean and one standard deviation about the mean of the normalized measurements. The data are discussed below under headings associated with each of the gamma dosimeter types used in PDIS 14 as well as the composite of all gamma results. It should be pointed out that not too much should be inferred rirom exposure 6 since the reference gamma component was only $10^{-5} \mathrm{~Sv}(1 \mathrm{mrem})$.

TLD-100

Three participants (numbers 11, 42A, and 42B) used TLD-100 to measure the gamma component in these mixed field neutron-gamma exposures. Being natural $\mathrm{LiF}$, these dosimeters are expected to be relatively sensitive to neutrons. That explains the severe overestimation of the gamma dose equivalent as seen in Figure 7. The overresponse increases with increasing neutron-to-gamma dose equivalent ratio $(\mathrm{N} / \mathrm{G})$. The average overresponse was only about $50 \%$ for exposure 2 which was the ${ }^{137} \mathrm{Cs}$ enhanced ${ }^{252} \mathrm{Cf}$ (poly) exposure with $\mathrm{N} / \mathrm{G}=0.32$. In the other exposures where $\mathrm{N} / \mathrm{G}>4$, the average overresponse varied from a factor of 4.5 - 9. An examination of Tables 21-26 shows that, in some cases, individual participants reported results which were high by a factor of 22 .

\section{TLD-700}

About $35 \%$ of PDIS 14 gamma measurements made with TLD's were made with TLD-700 dosimeters.

The average performance is shown graphically in Figure 7. The general trend is toward increasing overresponse with increasing $\mathrm{N} / \mathrm{G}$; however, more explanation is needed. The most accurate measurements were made for the high dose equivalent (i.e., $185 \times 10^{-5} \mathrm{~Sv}$ ), low $\mathrm{N} / \mathrm{G}$ (i.e., 0.32 ) exposure (number 2). The least accurate overall results were associated with exposure 4 (no cadmium). The average TLD-700 results for this $42\left(10^{-5}\right)$ Sv exposure were high by a factor of 2.41 . Examination of 
Table 18 shows that this unexpectedly poor accuracy was due to the results of two participants, numbers 1 and 41C, being high by factors of 6.17 and 15.5, respectively. If those two results were omitted, the normalized average would be $1.02 \pm 0.32$. A comparison of exposures 3 and 5 shows that the dose equivalent at $60^{\circ}$ incidence is $75 \%$ of that at perpendicular incidence (it was $76 \%$ for TLD-100).

\section{TLD-BeO}

One participant (number 8) used TLD-BeO dosimeters. Their results, except for exposures 1 and 6 where they reported $\leq 20\left(10^{-5}\right) \mathrm{Sv}$, are plotted in Figure 7. They generally underestimated the dose equivalent in exposures $2-5$ by $8-29 \%$. Their results at $60^{\circ}$ incidence were $90 \%$ of those at perpendicular incidence.

\section{TLD-CaSO}

Near the front of this report, it was stated that $54 \%$ of PDIS 14 TLD-using participants used $\mathrm{CaSO}_{4}$ either alone or in combination with $\mathrm{Li}_{2} \mathrm{~B}_{4} \mathrm{O}_{7}$. For this gamma analysis, the term "TLD-CaSO ${ }_{4}$ " is used to identify Teledyne-type dosimeters. The term "TLD- $\mathrm{Li}_{2} \mathrm{~B}_{4} \mathrm{O}_{7}{ }^{n}$ is used (see the next section) to identify Panasonic-type dosimeters even though some of the:n use the $\mathrm{CaSO}_{4}$ portion to obtain the gamma results.

According to the definition of terms we have adopted, three participants used TLD-CaSO ${ }_{4}$. As seen in Figure 7, they obtained excellent results for exposures 1-3. Their average results were within 4\% of reference values for these exposures and the standard deviations were small. Such values (when exposure 3 is considered) indicate a very weak angular dependence for these dosimeters in the gamma fields in which they were tested. They measured "zero" dose equivalent for exposure 6, but the reference value was only $10^{-5} \mathrm{~Sv}$. Exposure 5 results indicate a dramatic overresponse. This was due to the fact that one participant (number 34 ) reported a value which was high by a factor of 15.8 . If 
that result is omitted, the average of the remaining two participants is high by only $9 \%$. The results for the "no-cadmium" exposure (i.e., number 4 ) were high by $<30 \%$. Considering everything, these dosimeters performed quite well.

TLD- $\mathrm{Li}_{2} \mathrm{~B}_{4} \mathrm{O}_{7}$

As explained in the previous section, "TLD- $\mathrm{Li}_{2} \mathrm{~B}_{4} \mathrm{O}_{7}$ ". refers to Panasonic-type dosimeters in this analysis. In PDIS 14, $46 \%$ of TLD using participants used this type TLD gamma dosimeter. The results, as seen in Figure 7, are lower than the reference values for exposures 1-3, and 5. They are, however, within $28 \%$ of reference values for all exposures except the $10^{-5} \mathrm{~Sv}$ one (number 6 ) where they overestimate by a factor of 3. A comparison of exposures 3 and 5 shows that the average response at $60^{\circ}$ is $90 \%$ of that at perpendicular incidence. The average gamma response for the "no cadmium" case (exposure 4) was $11 \%$ greater than for the standard ${ }^{252} \mathrm{Cf}\left(\mathrm{D}_{2} \mathrm{O}\right)$ exposure (number 5 ). These dosimeters exhibited the best overall performance of any gamma dosimeter type for exposures 4 and 5.

Film

About 16\% of PDIS 14 participants used film gamma dosimeters. As seen in Figure 7, the film response relative to reference values increases monotonically with N/G. Film results are excellent (within $8 \%$ of reference) for exposures $1-3$. The overresponse increases to $27 \%$ and $47 \%$ for exposures 5 and 4, respectively. Again, exposure 6 was only $10^{-5} \mathrm{~Sv}$ and not much can be gained from its analysis, The response at $60^{\circ}$ incidence was $85 \%$ of that at perpendicular incidence. It is noteworthy that the standard deviations for the film results were among the lowest of all gamma dosimeter types for all exposures. 


\section{Composite of gamma results}

A subset of all gamma reported results is presented in Figure 8 for each of the six exposures. Results greater than three times the reference values (about $8 \%$ of those reported) are excluded from the analysis. Half of those excluded were from exposure 6. The composite results were very good: they ranged from $17 \%$ underresponse to $14 \%$ overresponse and generally had higher results as $\mathrm{N} / \mathrm{G}$ increased. The standard deviations were reasonable and averaged about $30 \%$ of the mean for all but exposure 6. The average response at $60^{\circ}$ incidence was $96 \%$ of that at perpendicular incidence. That indicates almost no angular dependence for the relatively hard gammas associated with these exposures. Like the composite results for neutrons, the average response to ${ }^{252} \mathrm{Cr}\left(\mathrm{D}_{2} \mathrm{O}\right)$ without the cadmium sheet was greater than that for the "with cadmiurn" exposure by about $15 \%$.

\section{RESULTS AND ANALYSIS OF THE TOTAL DOSE EQUIVALENT}

Table 27 summarizes data from a subset of the composite total (i.e., neutron plus gamma) dose equivalents reported by participants. As before, the subset omits results which were greater than three times the reference values (about $6 \%$ of reported results were omitted). Relevant data are plotted in Figure 9. These results show that the mean total dose equivalents vary from $97-139 \%$ of reference values for the six PDIS 14 exposures. The mean results were most accurate for the $45\left(10^{-5}\right) \mathrm{Sv} \mathrm{PuBe}$ exposure (number 6), but the standard deviation was the largest. The least accurate results were obtained for the exposure to ${ }^{252} \mathrm{Cf}\left(\mathrm{D}_{2} \mathrm{O}\right)$ without the cadmium shell around the sphere. The average total dose equivalent was $17 \%$ higher for the exposure "without cadmium" than for the identical exposure with cadmium. Overall, the total dose equivalent for ${ }^{252} \mathrm{Cr}\left(\mathrm{D}_{2} \mathrm{O}\right)$ at $60^{\circ}$ incidence was $82 \%$ of that at perpendicular incidence.

\section{RESULTS RELATIVE TO REGULATORY CRITERIA}

Results relative to two different types of regulatory criteria (one traditional, one current) are presented in this section. 


\section{Nuclear Regulatory Commission}

Traditional guidance in the United States from the Nuclear Regulatory Commission ${ }^{31}$ (NRC) suggests that personnel neutron and gamma ray dosimeters used in the dose equivalent range covered by this study should be accurate to within ${ }_{5} 50 \%$ of reference values. A detailed examination of Tables 3-8 shows that $70 \%$ of the individual reported neutron dose equivalent measurements meet the ${ }_{ \pm} 50 \%$ accuracy criterion. For the traditional ${ }^{252} \mathrm{Cf}\left(\mathrm{D}_{2} \mathrm{O}\right)$ irradiations of exposures 1,3 , and 5 , about $76 \%$ of the neutron measurements meet the criterion. For exposures 2, 4, and 6, about $64 \%$ of the measurements are within $\pm 50 \%$ of reference values.

A similar examination of Tables $15-20$ shows that $90 \%$ of the individual reported gamma dose equivalent measurements meet the ${ }_{ \pm} 50 \%$ accuracy guidarce. This doesn't include the data for exposure 6 where only $25 \%$ of the measurements are within ${ }_{ \pm} 50 \%$ of the $10^{-5} \mathrm{~Sv}(1 \mathrm{mrem})$ dose equivalent value. As expected, $98 \%$ of the gamma measurements for the ${ }^{137} \mathrm{Cs}$-enhanced exposure of $185\left(10^{-5}\right)$ Sv (i.e., number 2 ) are within the accuracy guidelines.

A study of Figure 5 reveals that the mean measured neutron dose equivalents for TLD albedo neutron dosimeters meet the $\pm 50 \%$, criterion for all six exposures. Bubble and combination dosimeter results meet the criterion for five exposures, TLD's meet it for four, film for three, and track for only one of the six exposures.

A similar study of Figure 7 shows that the mean measured gamma dose equivalents for film and TLD. $\mathrm{Li}_{2} \mathrm{~B}_{4} \mathrm{O}_{7}$ meet the ${ }_{5} 50 \%$ guidance for five of the six exposures. TLD-BeO, $\mathrm{CaSO}_{4}$, and TLD-700 meet it for four, and TLD-100 for only one of the six exposures. 


\section{National Voluntary Laboratory Accreditation Program}

The National Voluntary Laboratory Accreditation Program (NVLAP) ${ }^{8}$ requires testing of personnel dosimeters based on American National Standards Institute criteria ${ }^{32}$. For suin testing, NVLAP requirements are that the absolute value of the normalized sum, T, of the accuracy (i.e., mean result minus reference) and the precision (one standard deviation about the mean) must be $s 0.50$. PDIS 14 exposures were generally more difficult to measure than those currently required by NVLAP, but it is of interest to evaluate the results according to the NVLAP criteria.

Careful study of Tables 9-14 allows the calculation of $\mathrm{T}$ for the various exposures and neutron dosimeter types. When all neutron dosimeters are considered as a group, they don't meet the $T \leq 0.50$ requirement for any PDIS 14 exposure ( $T$ varied from $0.66-2.40$ ). The same is true for the subset ( $T$ varied from $0.64-0.91$ ). As a group, TLD albedo ( $\mathrm{T}$ of $0.53-2.06$ ) and track ( $\mathrm{T}$ of 1.08-4.97) dosimeters do not meet the requirement for any exposure. TLD (exposure 3) and film (exposure 6) meet it for one exposure. Bubbie dosimeters ( $T$ of $0.15-0.65$ ) meet the requirement for three of the six exposures and combination dosimeters meet the NVLAP requirement for five expcsures (only missed number 6).

A similar study of Tables 21-26 allowed the calculation of $T$ for the various exposures and gamma dosimeter types. When all gamma dosimeters are considered as a group, they only meet the $T \leq 0.50$ requirement for PDIS 12 exposure $2(T=0.26)$. The subset, however, meets the requirement for five exposures; only exposure $6(\mathrm{~T}=0.98)$ failed. As a group, TLD-100 dosimeters do not meet the requirement for any exposure ( $\mathrm{T}$ of $0.99-17.26$ ). TLD-BeO was not considered since only one participant used that type of dosimeter. TLD-700 dosimeters meet the requirement for one exposure (number 2). Film, $\mathrm{CaSO}_{4}$, and $\mathrm{Li}_{2} \mathrm{~B}_{4} \mathrm{O}_{7}$ meet the NVLAP $\mathrm{T} \leq 0.50$ requirement for four of the six PDis 14 exposures. 


\section{ADDITIONAL PARTICIPANT-FURNISHED INFORMATION}

Most participants completed a questionnaire designed to collect additional dose equivalent determination methodology and returned it with their measured results. It was learned that all participant organizations, except two who purchase vendor services, evaluated the dosimeters in-house. Additional results of the questionnaire are summarized in the following text.

When the neutron dose equivalent is reported, it has to be reported using some particular reporting convention ${ }^{23}$. Seventeen participants ( $44 \%$ of those responding to the question) used the ICRP $21^{19}$ reporting convention. This is the one which we primarily use at DOSAR. The convention described by the National Council on Radiation Protection and Measurements in Report No. $38^{33}$ (i.e., NCRP 38) was used by $31 \%$ of those reporting. Four other conventions were used by $18 \%$ of those responding to the questionnaire and $7 \%$ did not know which convention was in use by their organization.

Calibration is an important part of neutron dosimetry. Twelve participants (33\% of those responding) used $\mathrm{D}_{2} \mathrm{O}$-moderated ${ }^{252} \mathrm{Cf}$ either alone or in combination with another source to calibrate their dosimeters. Nine participants $(25 \%)$ said they used ${ }^{252} \mathrm{Cf}$ (alone or in combination with others). We suspect that some of these may have actually been moderated and not just bare ${ }^{252} \mathrm{Cr}$. AmBe sources (alone or in combination) were used by $19 \%$ of the respondents while PuBe was used by $17 \%$. One participant (3\%) used ${ }^{137} \mathrm{Cs}$ and another (3\%) said they didn't use anything.

Corrections to raw readings of the neutron dose equivalent can be made in a variety of ways. We assume that all participants corrected for background and asked what other corrections were made. Eleven respondents (30\%) didn't make further corrections. Six (16\%) made "energy corrections." The other 20 respondents listed 9 different types of corrections they made. Among those types were fading (film users), temperature (bubble user), 9/3-inch ratio (could be an seen as an energy correction), and track size analysis. 


\section{SUMMARY AND CONCLUSIONS}

The following summary and conciusions are based on PDIS 14 information presented in the text, tables, and figures.

1. More participants (40\%) measured the neutron dose equivalent with TLD albedo dosimeters than with any other type. The second most used neutron dosimeter type was the direct interaction TLD (22\%).

2. TLD systems of various types were used by $84 \%$ of PDIS 14 participants to measure the gamma dose equivalent. Of these, $54 \%$ were $\mathrm{CaSO}_{4}$ (alone or in combination with $\mathrm{Li}_{2} \mathrm{~B}_{4} \mathrm{O}_{7}$ ) and $35 \%$ were ${ }^{7} \mathrm{LiF}$ (TLD-700).

3. More participants (44\%) reported their neutron dose equivalents in the convention advocated in ICRP 21 than in any other. About $31 \%$ used the NCRP 38 dose equivalent reporting convention.

4. About $58 \%$ of participants measuring neutrons calibrated their systems with ${ }^{252} \mathrm{Cf}$ (either bare or $\mathrm{D}_{2} \mathrm{O}$-moderated). AmBe (19\%) and PuBe (17\%) were other major sources used by PDIS 14 participants.

5. PDIS 14 was the first ORNL intercomparison in which bubble detectors were used to measure the neutron dose equivalent.

6. Neutron dose equivalents were more accurately measured for hard spectra than for soft spectra. 
7. Overall, measured gamma dose equivalents increased monotonically with increasing neutron-togamma dose equivalent ratio relative to reference values.

8. The average neutron dosimeter response to ${ }^{252} \mathrm{Cf}\left(\mathrm{D}_{2} \mathrm{O}\right)$ at $60^{\circ}$ incidence was $70 \%$ of that at perpendicular incidence. As expected, track (54\%) and film (60\%) exhibited the strongest angular dependence.

9. The average gamma dosimeter response to ${ }^{252} \mathrm{Cf}\left(\mathrm{D}_{2} \mathrm{O}\right)$ at $60^{\circ}$ incidence was $96 \%$ of that at perpendicular incidence. The value for film was $85 \%$.

10. The average neutron dosimeter response as well as the average gamma dosimeter response to ${ }^{252} \mathrm{Cf}\left(\mathrm{D}_{2} \mathrm{O}\right)$ without the cadmium shell around the steel sphere was $15 \%$ greater than that with the cadmium shell.

11. A total of $70 \%$ of individual reported neutron dosimeter measurements were within $\pm 50 \%$ of reference values. (76\% of measurements were within guidelines for ${ }^{252} \mathrm{Cf}\left(\mathrm{D}_{2} \mathrm{O}\right)$-type exposures).

12. A total of $90 \%$ of individual reported gamma dosimeter measurements were within $\pm 50 \%$ of reference values. (This does not consider the $10^{-5} \mathrm{~Sv}$ exposure number 6 ).

13. Based on a combination of accuracy and precision in the measurement of all PDIS 14 exposures, the neutron dosimeter types judged to have exhibited the best performance were combination, TLD-albedo, and bubble. 
14. Based on a combination of accuracy and precision in the measurement of five PDIS 14 exposures (number 6 is omitted), the gamma dosimeter types judged to have exhibited the best performance were TLD- $\mathrm{Li}_{2} \mathrm{~B}_{4} \mathrm{O}_{7}$, film, and $\mathrm{CaSO}_{4}$.

15. The use of TLD-100 dosimeters to measure the gamma component of mixed neutron-gamma radiation fields can lead to severe overresponse. For the six PDIS 14 exposures, the average overresponse of such dosimeters was more than a factor of 5 . 


\section{REFERENCES}

1. R. E. Swaja and C. S. Sims, "Neutron Personnel Dosimetry Intercomparison Studies at the Oak Ridge National Laboratory: A Summary (1981-1986), " Health Phys., 55, 549-564 (1988).

2. C. S. Sims and R. E. Swaja, "Personnel Neutron Dosimetry Intercomparison Studies at the Health Physics Research Reactor: A Summary (1974-1980)," Health Phys., 42, 3-18 (1982).

3. R. E. Swaja, L. E. West, C. S. Sims and T. J. Welty, 1987 Neutron and Gamma Personnel Dosimeter Intercomparison Study Using a $\mathrm{D}_{2}$ O-Moderated ${ }^{252}$ Cf Source, ORNL-6544 (May 1989).

4. R. E. Swaja, P. S. Weng, C. S. Sims and S. H. Yeh, Summary and Analysis of the 1986 ORNL Personnel Dosimetry Intercomparison Study, ORNL-6378 (April 1987).

5. William H. Casson and C. S. Sims, "A inew Dosimeter Calibration Laboratory at ORNL," in Proceedings of the Second Conference on Radiation Protection and Dosimetry, p. 206-210, ORNL/TM-10971 (October 1988).

6. C. S. Sims and H. W. Dickson, "Neutron Dosimetry Intercomparison Studies," Radiat. Prot. Dosim., 10 , 331-340 (1985).

7. C. S. Sims and L. W. Gilley, "Twenty Years of Health Physics Research Reactor Operation," Nuclear Safety, 24, 678-688 (1983).

8. Robert L. Gladhill, Jeffrey Horlick and Elmer Eisenhower, The National Personnel Radiation Dosimetry Accreditation Program, U. S. Department of Commerce, National Bureau of Standards, NBSIR 86-3350 (January 1986).

9. U. S. Department of Energy, Handbook for the Department of Energy Laboratory Accreditation Program for Personnel Dosimetry Systems, DOE/EH-0026 (December 1986).

10. R. E. Apfel and Y. C. Lo, "Practical Neutron Dosimetry with Superheated Drops," Health Phys., 56, 79-83 (1989).

11. H. Ing, "The Status of the Bubble-Damage Polymer Detector," Nucl. Tracks and Radiat. Meas., 12, 49-54 (1986).

12. R. V. Griffith, D. E. Hankins, R. B. Gammage, L. Tommasino and R. V. Whecler, "Recent Developments in Personnel Neutron Dosimeters: a Review," Health Phys., $\underline{36}$, 235-260 (1979).

13. H. Ing and E. Piesch, eds., "Neutron Dosimetry in Radiation Protection," Radiat. Prot. Dosim., 10, 1-345 (1985).

14. M. Sohrabi, "Review of Recent Developments in Personnel Neutron Dosimeters," Health Phys., 41, 686-689 (1981).

15. K. I. Duftschmid, "TLD Personnel Monitoring Systems-The Present Situation," Radiat. Prot. Dosim., 2, 3-12 (1982).

16. C. S. Sims and R. E. Swaja, "TLD-700 Gamma Measurements in Mixed Neutron-Gamma Radiation Fields," Riddiat. Prot. Dosim., 12, 325-331 (1986). 
17. Yigal S. Horowitz, Thermoluminescence and Thermoluminescent Dosimetry, Volumes I-III, CRC Press, Boca Ratan, Florida (1984).

18. H. Awschalom and R. S. Sanna, "Application of Bonner Sphere Detectors in Neutron Field Dosimetry," Radiat. Prot. Dosim., 10, 89-101 (1985).

19. International Commission on Radiological Protection, "Data for Protection Against Ionizing Radiation from External Sources: Supplement to ICRP Publication 15," ICRP Publication 21 (1973).

20. R. B. Schwartz and C. M. Eisenhauer, Procedures for Calibrating Neutron Personnel Dosimeters, U. S. Department of Commerce, National Bureau of Standards, Washington, D. C., NBS Special Putlication 633 (1982).

21. C. M. Eisenhauer, J. B. Hunt and R. B. Schwartz, "Calibration Techniques for Neutron Personnel Dosimetry," Radiat. Prot. Dosim., 10, 43-57 (1985).

22. S. Block, J. Bryan, C. Prevo and D. Montan, "Laboratory Sources Enhanced in $0.5 \mathrm{eV}$ to 200 keV Neutrons for Instrument Evaluation," Health Phys., 13, 1025-1031 (1967).

23. C. S. Sims, "Comparison of Neutron Dosimetric Quantities,"

24. C. M. Eisenhaucr, "Evaluation of Dose Equivalent per Unit Fluence for a $\mathrm{D}_{2} \mathrm{O}$-Moderated ${ }^{252} \mathrm{Cf}$ Neutron Source," Radiat. Prot. Dosim., 9, 63-64 (1984).

25. U. S. Department of Energy, Department of Energy Standard for the Performance Testing of Personnel Dosimetry Systems, DOE/EH-0027 (December 1986).

26. M. Awschalom and R. S. Sanna, "Applications of Bonner Sphere Detectors in Neutron Field Dosimetry, ${ }^{,}$Radiat. Prot. Dosim.., 10, 89-101 (1985).

27. James C. Liu, ${ }^{2252} \mathrm{Cf}$ (Polyethylene Moderated) Dosimetry Information," internal ORNL lettert C. S. Sims (April 25, 1989).

28. James C. Liu, Ferenc Hajnal, C. S. Sims and John Kuiper, "Neutron Spectra Measurements at ORNL," submitted to Radiat. Prot. Dosim. on October 19, 1989.

29. R. Oyan and C. S. Sims, "Radiation Dose from HPRR Gamma Rays," Radiat. Prot. Dosim., 16, 213-217 (1986).

30. C. S. Sims and R. E. Swaja, "Performance Comparison of Thorium Track, Polycarbonate, and CR-39 Neutron Dosimeters," Nucl. Tracks, 시, 461-465 (1985).

31. U. S. Nuclear Regulatory Commission, Personnel Neutron Dosimetry, NRC Regulatory Guide 8.14, Rev. 1 (1977).

32. American National Standards Institute, Criteria for Testing Personnel Dosimeter Performance, ANSI N 13.11 (January 1983).

33. National Council on Radiation Protection and Measurements, "Protection Against Neutron Radiation," NCRP Report Number 38 (1971). 


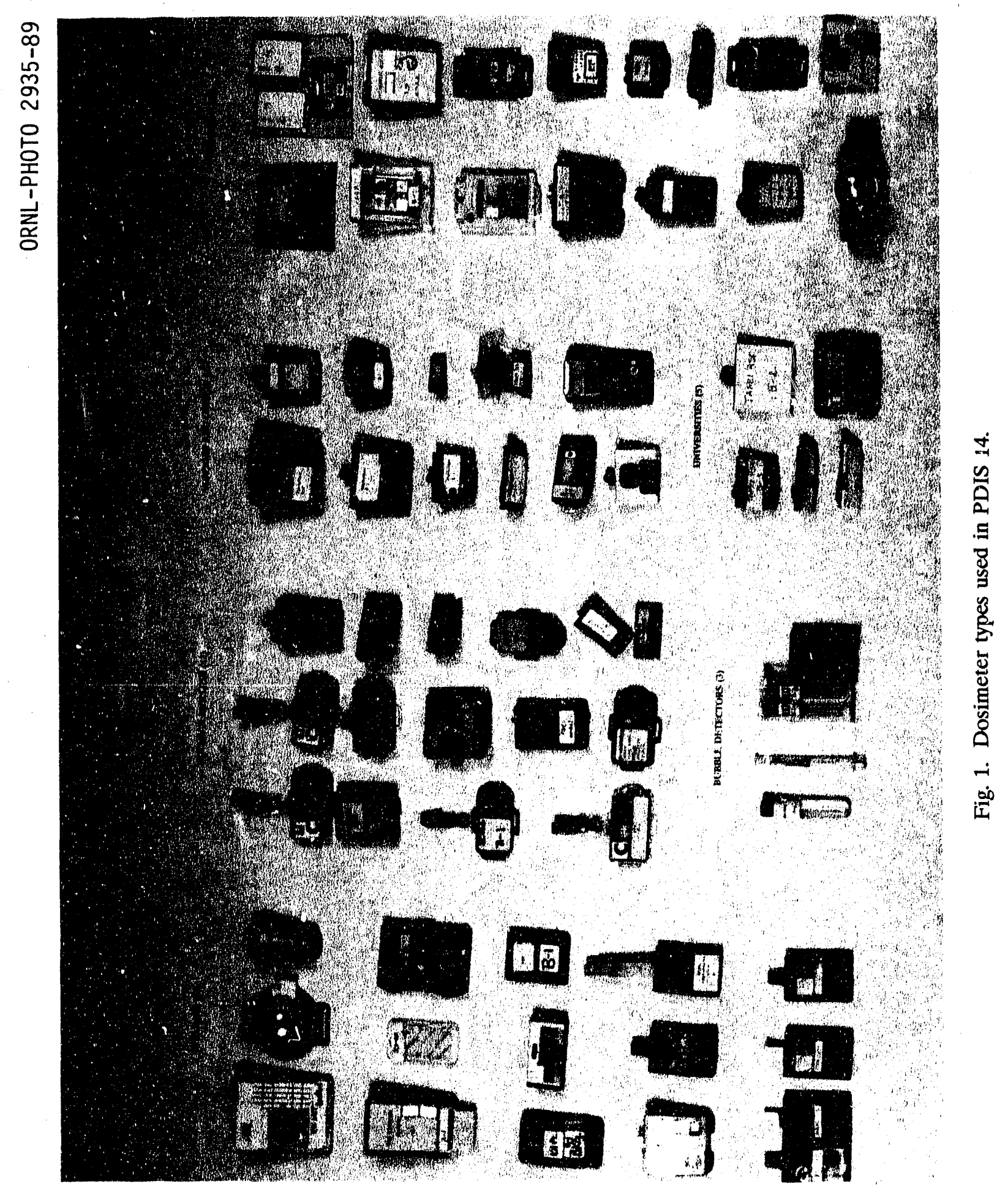




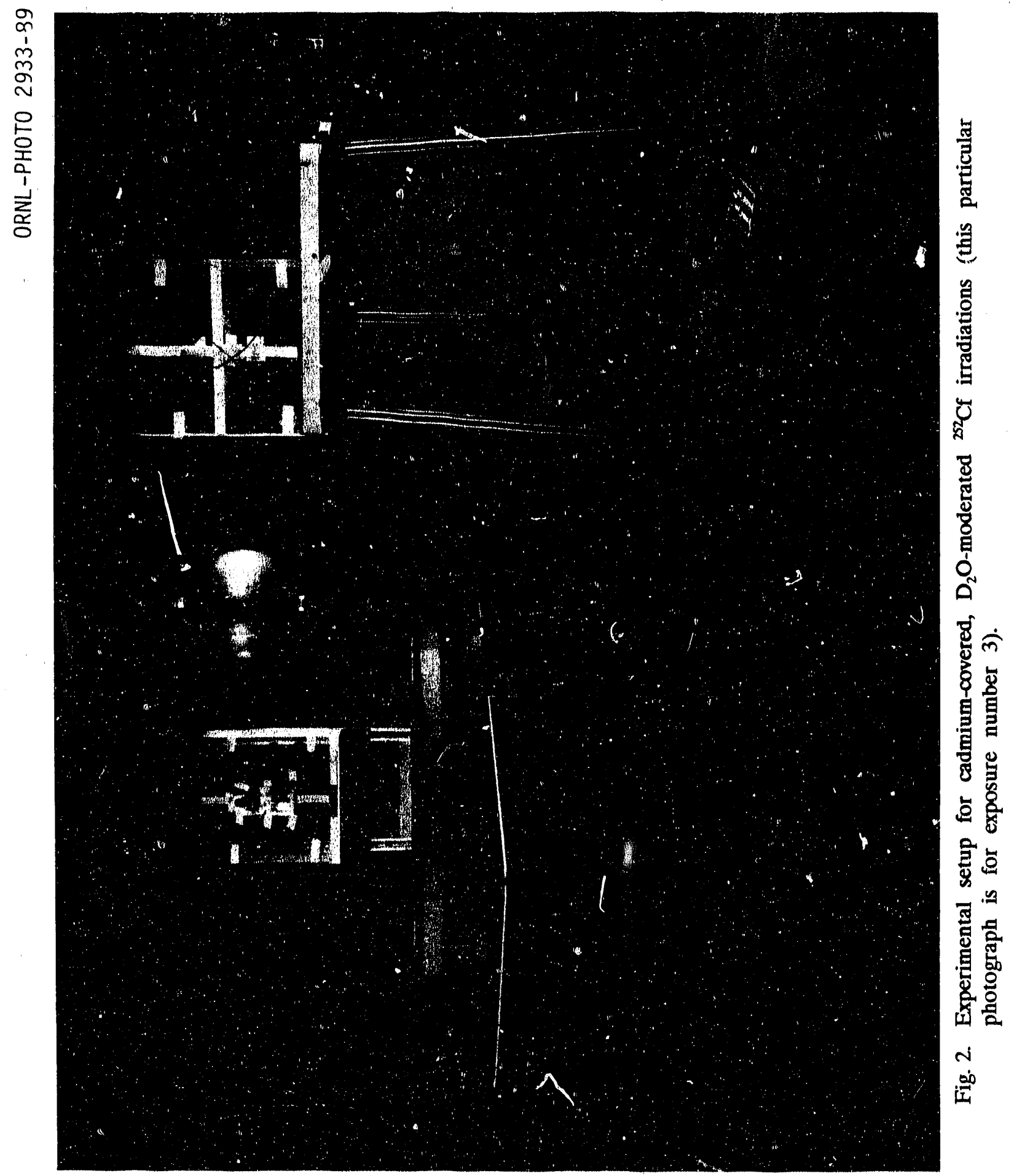




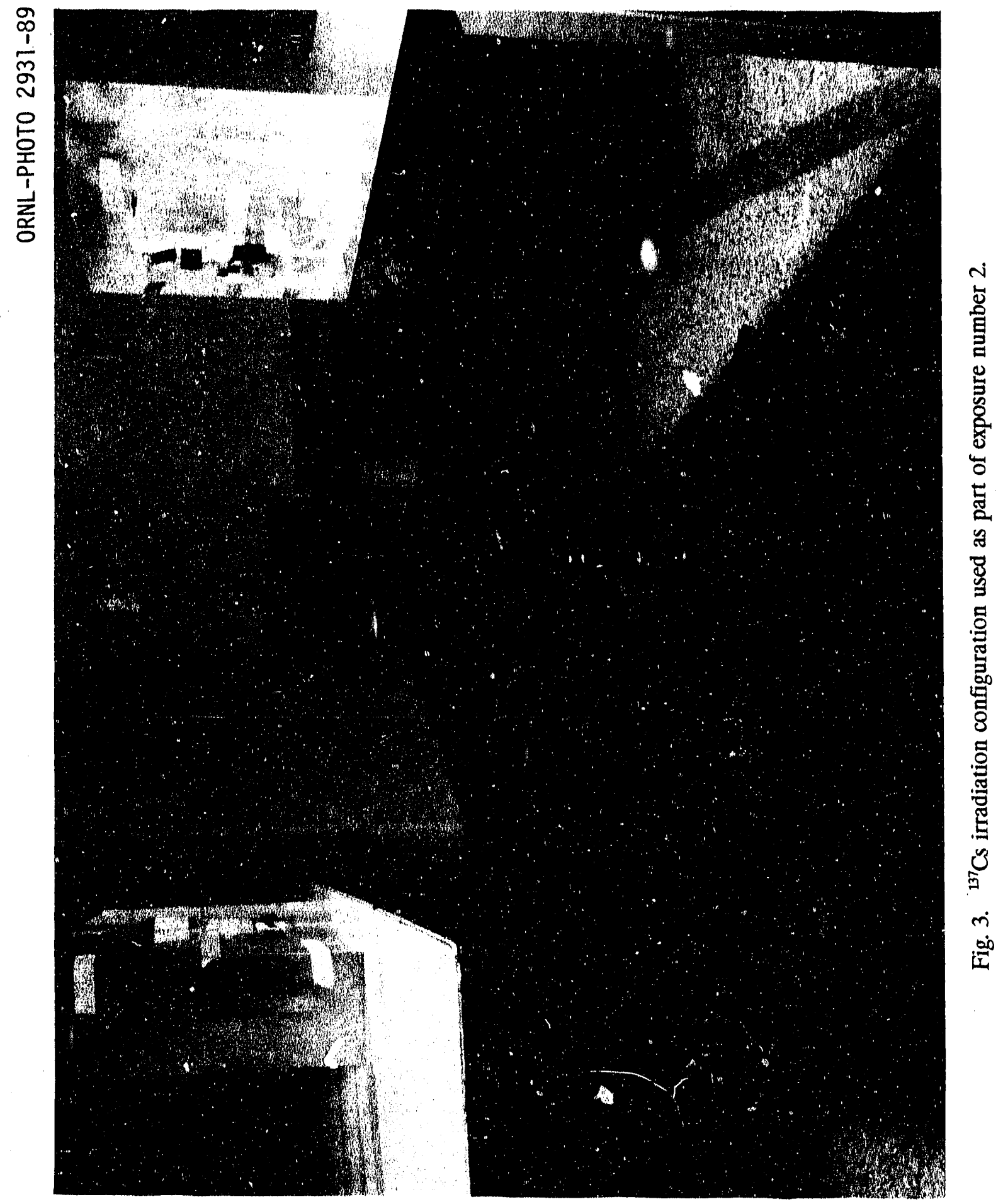




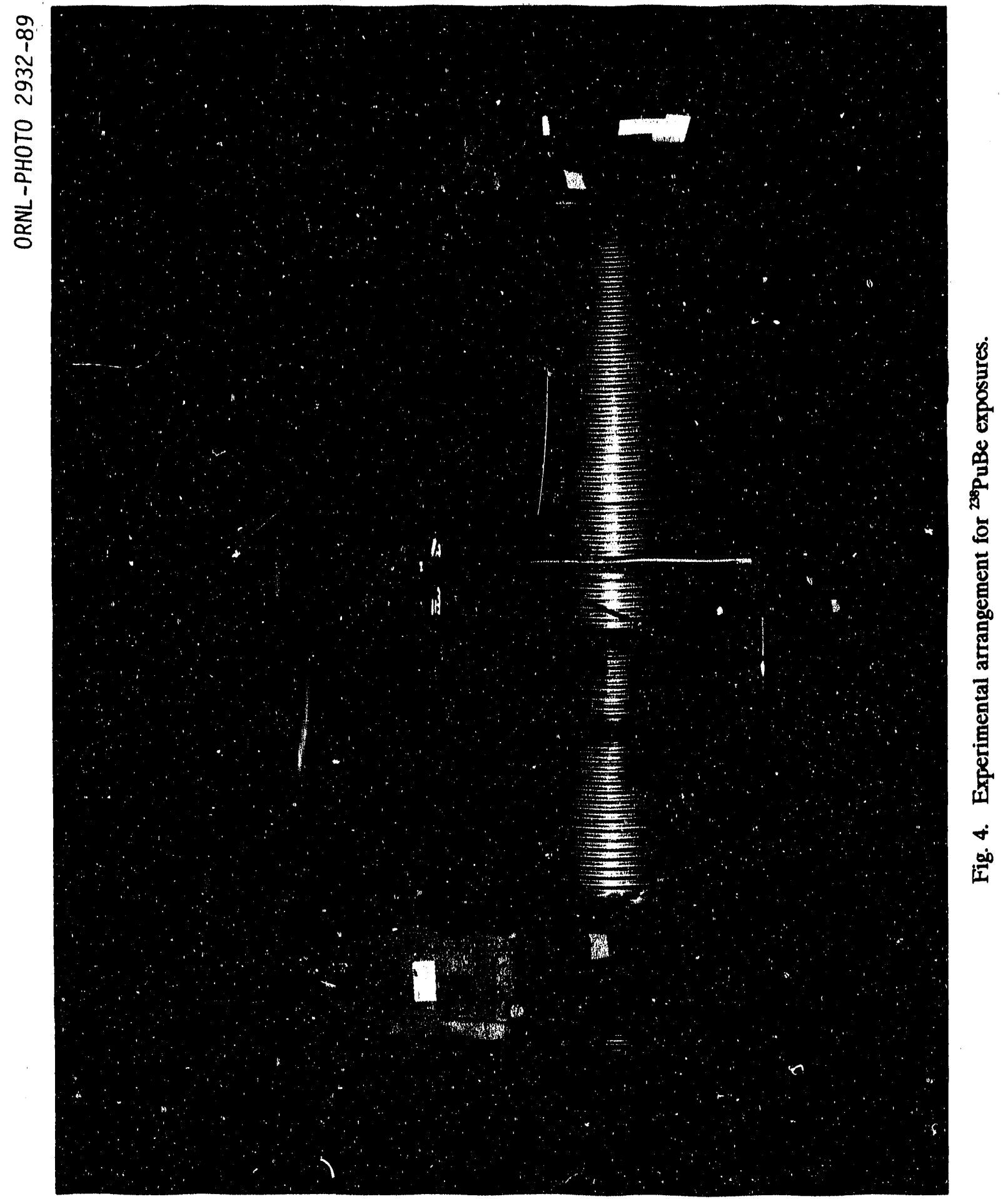


ORNL-DWG 90M-10367

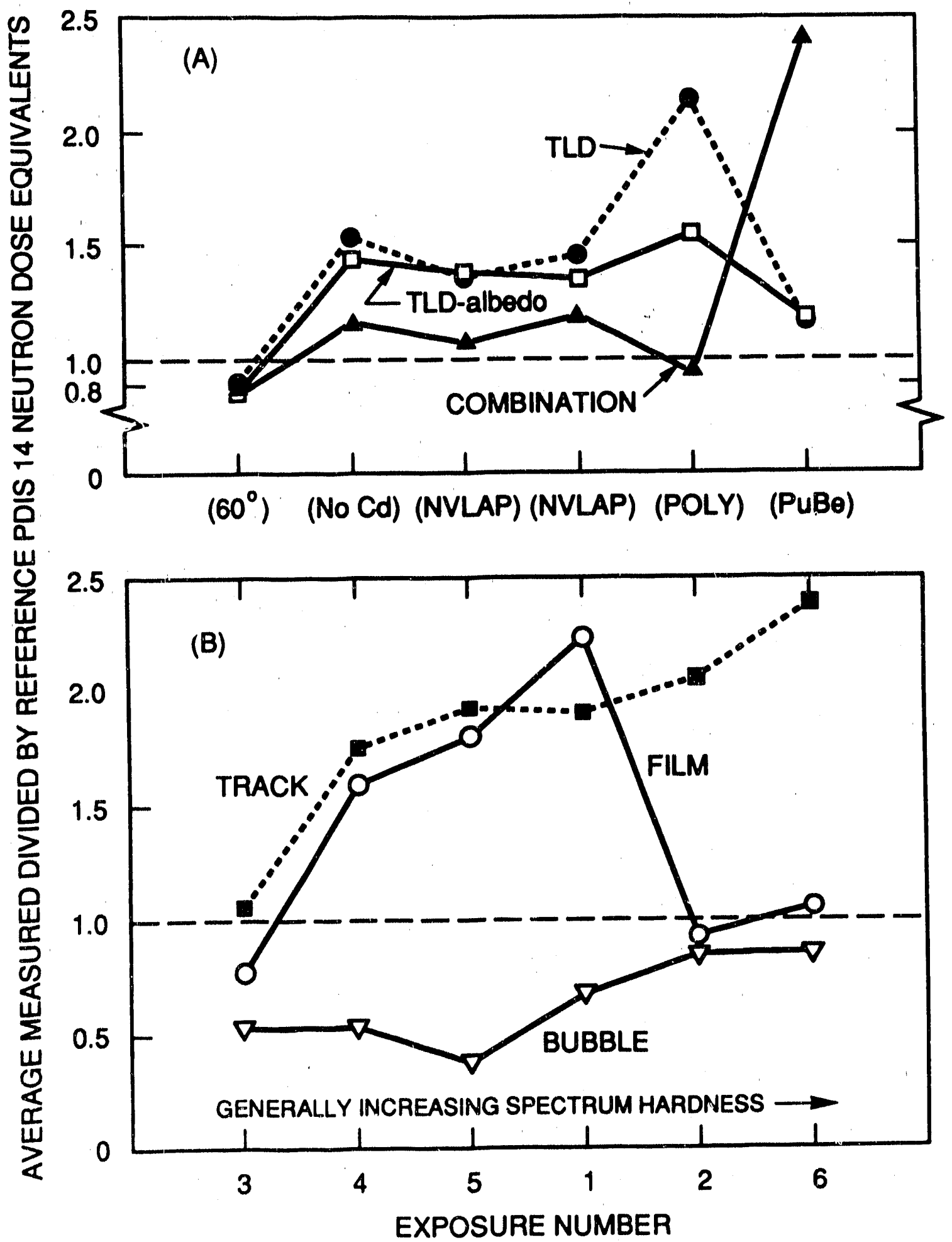

Fig. 5. Average measured neutron dose equivalents presented by type of dosimeter. 
ORNL-DWG 90M-10368

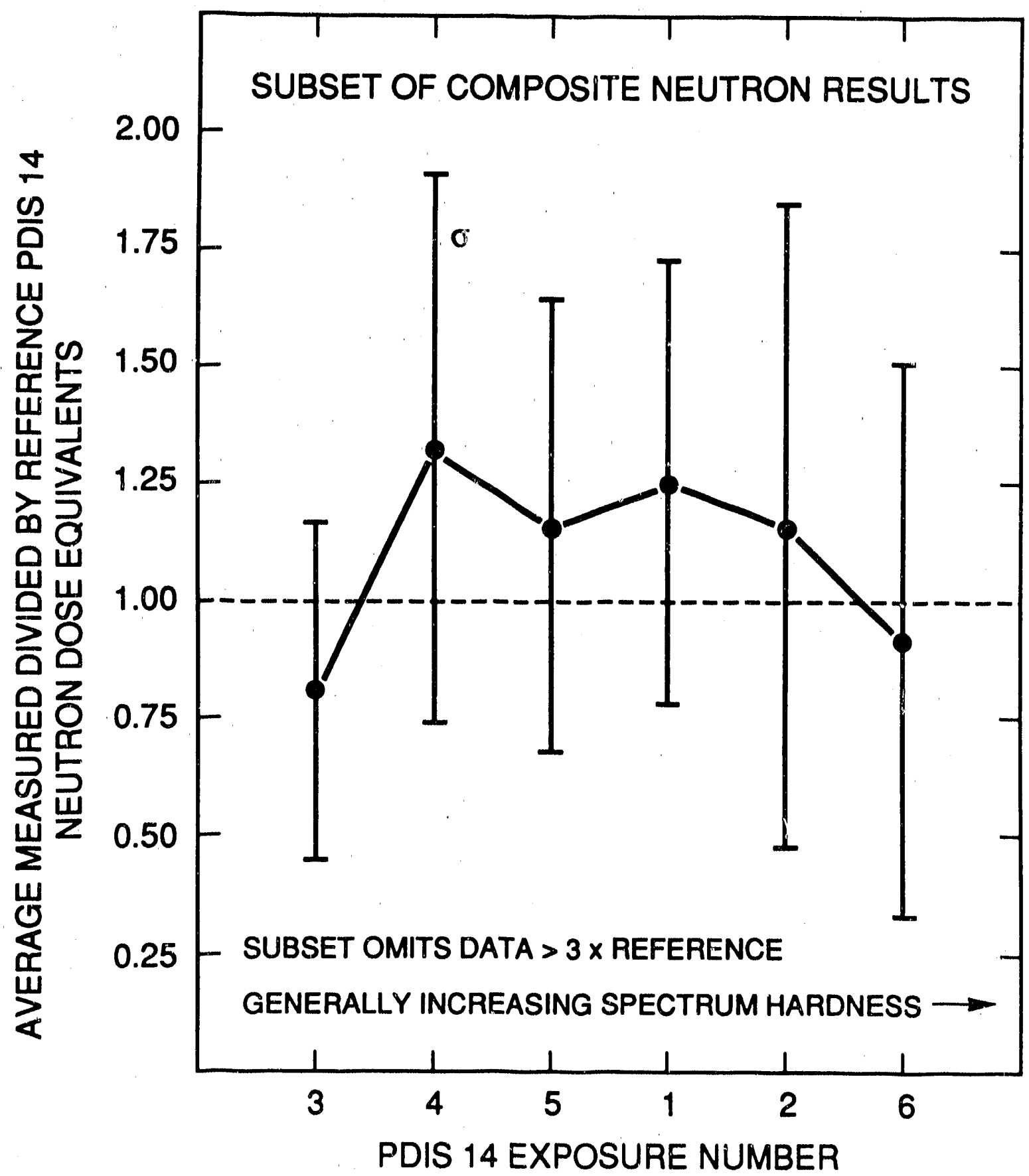

Fig. 6. Average measured neutron dose equivalents in PDIS 14. 


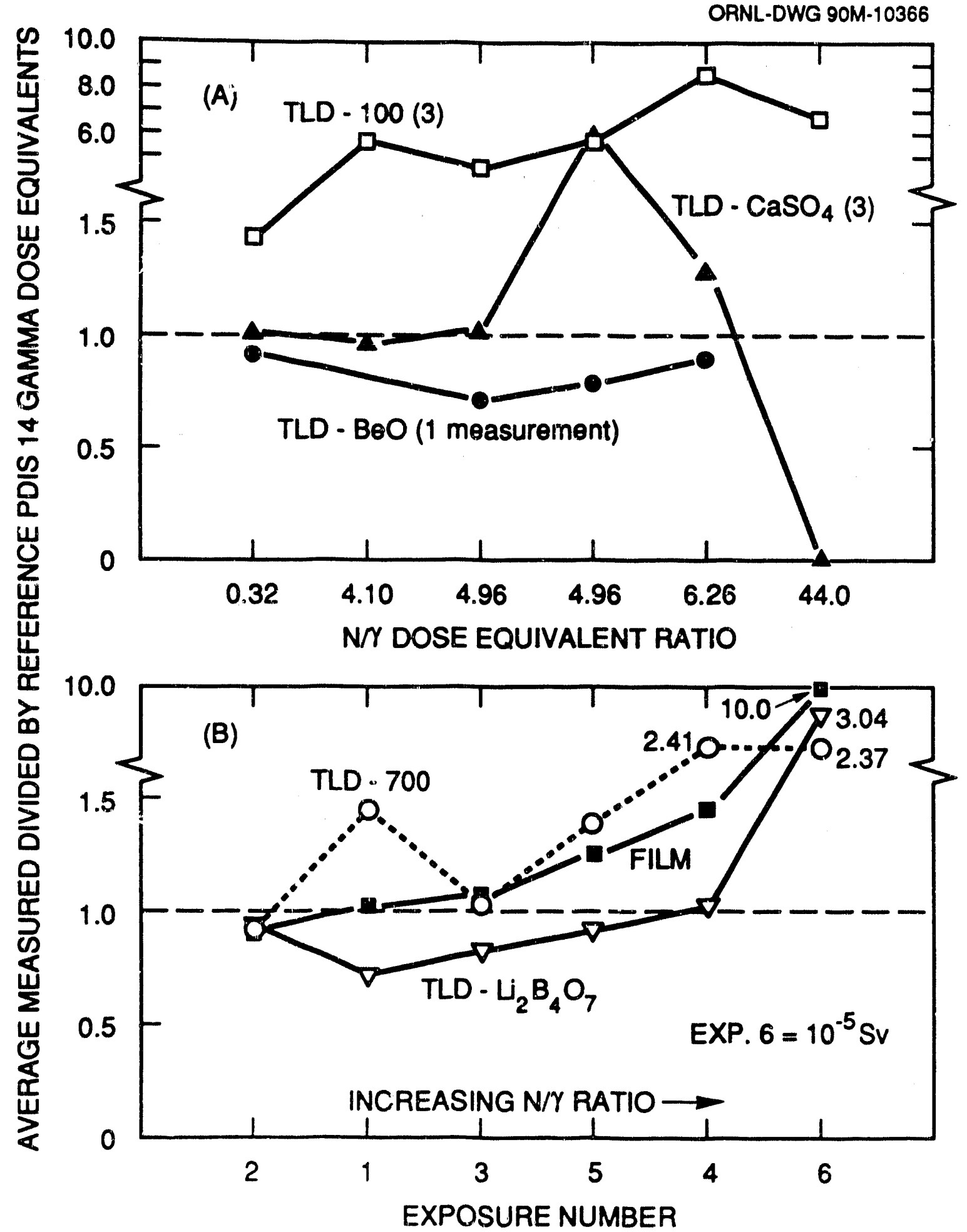

Fig. 7. Average measured gamma dose equivalents presented by type of dosimeter. 
ORNL-DWG 90M-10369

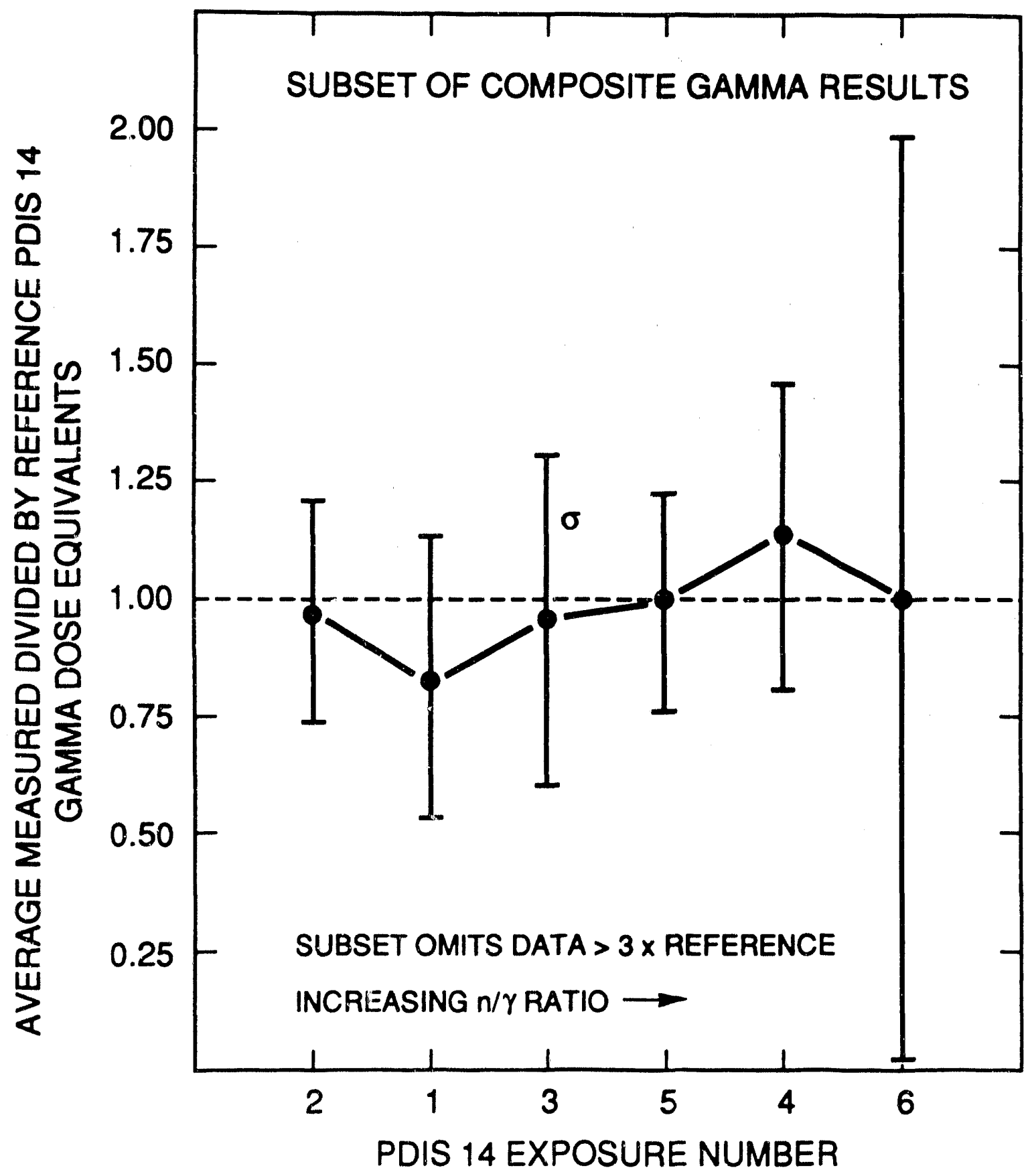

Fig. 8. Average measured gamma dose equivalents in PDIS 14. 


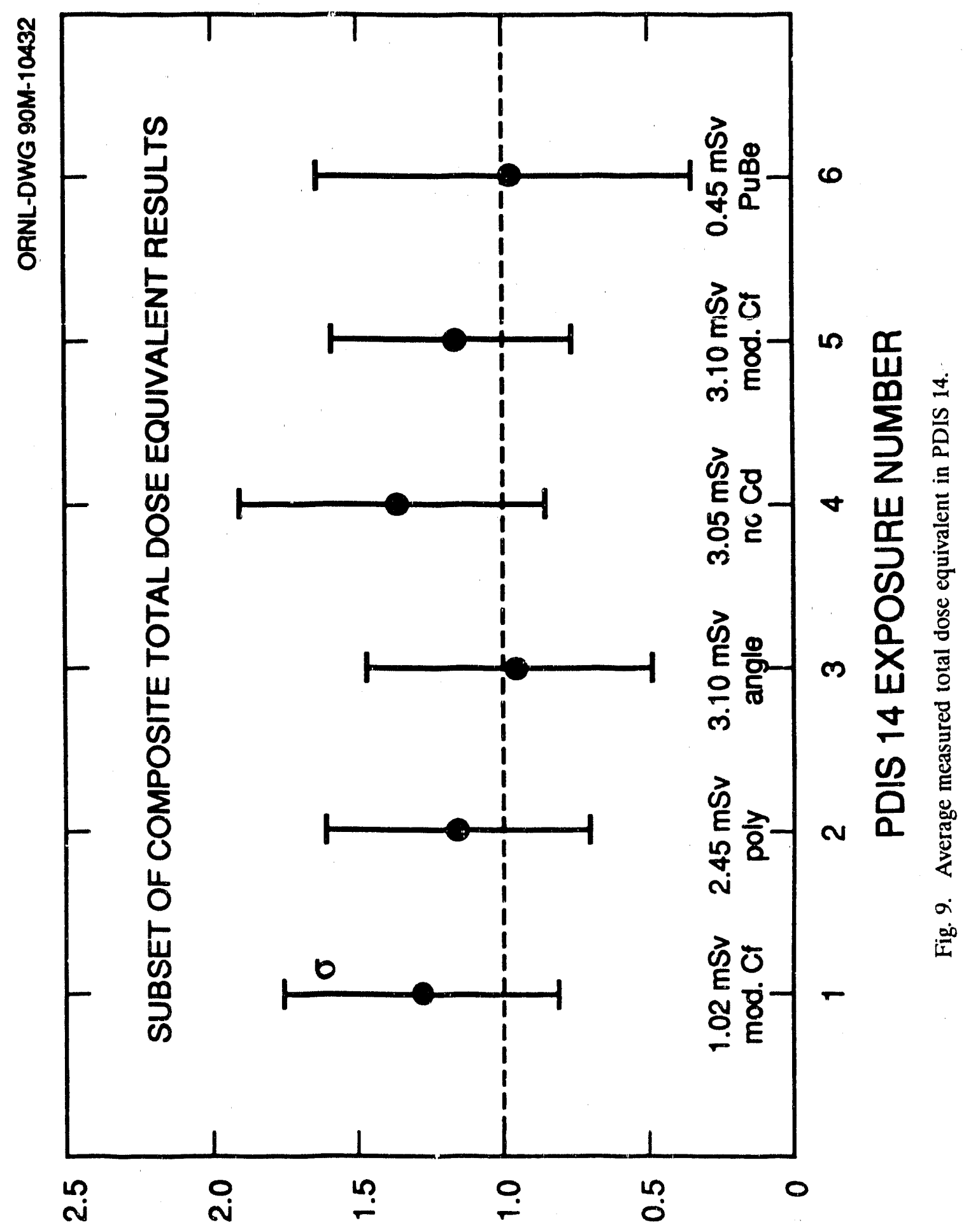

$\perp N \exists 7 \forall \wedge I \cap O \exists \exists S O O 7 \forall \perp O \perp$

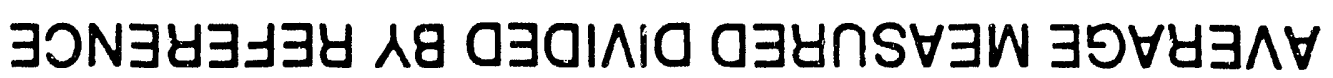


Table 1. Radiation exposure conditions for PDIS 14

\begin{tabular}{|c|c|c|c|c|c|}
\hline $\begin{array}{l}\text { Exposure } \\
\text { Number }\end{array}$ & $\begin{array}{l}\text { Source } \\
\text { Description }\end{array}$ & $\begin{array}{l}\text { Distance } \\
\text { (meters) }\end{array}$ & Datc(s) & $\begin{array}{c}9 / 3^{\prime \prime} \\
\text { Ratio }\end{array}$ & $\begin{array}{l}\text { Avg. Neutron } \\
\text { E (Mev) }\end{array}$ \\
\hline 1 & $15-\mathrm{cm} \mathrm{D}_{2} \mathrm{O}$-moderated ${ }^{252} \mathrm{Cf}$ & 1.5 & $5 / 2 / 89$ & 0.26 & 0.55 \\
\hline 2 & $\begin{array}{l}{ }^{252} \mathrm{Cf} \text { moderated by } 15-\mathrm{cm} \\
\text { polyethylene enhanced by } \\
\text { gammas from }{ }^{137} \mathrm{Cs}\end{array}$ & $\begin{array}{l}1.0 \\
0.51\end{array}$ & $\begin{array}{l}5 / 1 / 89 \\
5 / 1 / 89\end{array}$ & 0.74 & 0.86 \\
\hline 3 & $\begin{array}{l}\mathrm{D}_{2} \mathrm{O} \text {-moderated }{ }^{252} \mathrm{Cf} \text { rotated } \\
60^{\circ} \text { clockwise about vertical } \\
\text { centerline }\end{array}$ & 0.75 & $5 / 2-4 / 89$ & 0.29 & 0.55 \\
\hline 4 & $\begin{array}{l}\mathrm{D}_{2} \mathrm{C} / \text {-moderated }{ }^{252} \mathrm{Cf} \text { without } \\
\text { thr, cadmium cover on the } \\
\mathrm{s} ! \text {, here }\end{array}$ & 0.75 & $5 / 3 / 89$ & 0.30 & $<0.55$ \\
\hline 5 & $15-\mathrm{cm} \mathrm{D}_{2} \mathrm{O}$-moderated ${ }^{252} \mathrm{Cf}$ & 0.75 & $5.2-3 / 89$ & 0.29 & 0.55 \\
\hline 6 & ${ }^{238} \mathrm{PuBe}$, unmoderated & 1.0 & $5 / 1-4 / 89$ & 3.06 & 4.00 \\
\hline
\end{tabular}

The distance shown in the above table is measured from the centerline of the source to the leading edge (i.e., surface nearest the source) of the phantom.

The ${ }^{252} \mathrm{Cr}$ irradiations were performed with the centerline of the source and the phantom at $1.83 \mathrm{~m}$ above the floor. This was $1.38 \mathrm{~m}$ for the ${ }^{238} \mathrm{PuBe}$ irradiations.

All exposure times were 20 minutes or less except for number 6 which was 105 minutes. 
Tabie 2. PDIS 14 reference dosimetry"

\begin{tabular}{|c|c|c|c|c|c|}
\hline $\begin{array}{l}\text { Exposure } \\
\text { Number }\end{array}$ & $\begin{array}{l}\mathrm{H}_{\mathrm{xpo}} \\
\left(10^{-5} \mathrm{~Sv}\right)\end{array}$ & $\begin{array}{l}\text { Scatter component, } \\
\text { room + air (\%) }\end{array}$ & $\begin{array}{l}\mathrm{H}_{\mathrm{p}^{5}} \\
\left(10^{5} \mathrm{~Sv}\right)\end{array}$ & $\begin{array}{l}\mathrm{H}_{8}^{\mathrm{c}} \\
\left(10^{5} \mathrm{SV}\right)\end{array}$ & $\begin{array}{l}H_{t}=H_{0}+H_{B} \\
\left(10^{5} \mathrm{~Sv}\right)\end{array}$ \\
\hline 1 & 69 & 19 & 82 & 20 & 102 \\
\hline 2 & 56 & 8 & 60 & $185^{d}$ & 245 \\
\hline $3^{e}$ & 246 & 5 & 258 & 52 & 310 \\
\hline $4^{f}$ & 250 & 5 & 263 & 42 & 305 \\
\hline 5 & 246 & 5 & 258 & 52 & 310 \\
\hline 6 & 42 & 5 & 44 & 1 & 45 \\
\hline
\end{tabular}

$10^{-5} \mathrm{~Sv}=1 \mathrm{mrem}$.

$\mathrm{H}_{\mathrm{npo}}=$ neutron dose equivalent due to primary beam only.

$\mathrm{H}_{\mathrm{n}}=$ scatter adjusted neutron dose equivalent (the real answer).

$\mathrm{H}_{\mathrm{g}}=$ gamma dose equivalent.

$\mathrm{H}_{\mathrm{t}}=$ total dose equivalent.

Notes: a. Reference values for the primary neutron beam were generally determined from NIST calibration of the sources and application of ICRP21 fluence-to-dose equivalent conversion factors. Exposure 2 values were determined from Bonner sphere measurements.

b. Scatter corrections were made using formulas advocated by NIST.

c. Reference gamma dose equivalents were generally measured with a Philips No. 18509 GM counter.

d. $\quad 147$ mrem from ${ }^{137} \mathrm{Cs}+38$ mrem from the moderated ${ }^{252} \mathrm{Cf}$.

e. Dose equivalent at perpendicular incidence.

f. The neutron fluence is $11 \%$ smaller with the cadmium cover in place than it is without it, but the dose equivalent difference is only about $1.5 \%$. (That's the difference in $H_{n}$ between exposures 4 and 5.) 
Table 3. Summary of reported neutron results for PDIS 14, exposure 1, $15-\mathrm{cm} \mathrm{D} \mathrm{D}_{2} \mathrm{O}$-moderatod ${ }^{252} \mathrm{C}, \mathrm{H}_{\mathrm{n}}=82\left(10^{-5}\right) \mathrm{Sv}$

\begin{tabular}{|c|c|c|c|c|c|}
\hline \multirow[b]{2}{*}{ Group } & \multirow{2}{*}{$\begin{array}{l}\text { Neutron dosimeter } \\
\text { type }\end{array}$} & \multicolumn{4}{|c|}{ Neutron dose equivakent $t^{b}, 10^{-5} \mathrm{~Sv}$} \\
\hline & & 1 & 2 & 3 & Average \\
\hline 1 & - & $\cdot$ & - & - & $\cdot$ \\
\hline 2 & Bubble & 45 & - & - & 45 \\
\hline 3 & TLD-albedo & 359 & 282 & 323 & 321 \\
\hline 4 & TLD-albedo & 130 & 140 & 140 & 137 \\
\hline 5 & TLD & 115 & 117 & 123 & 118 \\
\hline 6 & Film, Track & 220 & 260 & - & 240 \\
\hline 7 & TLD & 129 & 137 & 133 & 133 \\
\hline 8 & Track & 770 & 690 & 560 & 673 \\
\hline 9 & TLD & 120 & 135 & 130 & 128 \\
\hline 10 & TLD-albedo & 107 & 105 & 107 & 106 \\
\hline 11 & Track & 60 & 80 & 70 & 70 \\
\hline 12 & TLD-albedo & 62 & 55 & 61 & 59 \\
\hline 13 & Film & 280 & 250 & 240 & 257 \\
\hline $14 \mathrm{~A}$ & TLD & 98 & - & - & 98 \\
\hline $14 \mathrm{~B}$ & TLD-albedo & 81 & - & - & 81 \\
\hline $14 \mathrm{C}$ & Track & 64 & - & - & 64 \\
\hline $14 \mathrm{D}$ & Track & 85 & - & - & 85 \\
\hline 16 & TLD-albedo & 76 & 77 & 82 & 78 \\
\hline 17 & 'TLD-albedo \& Track & 120 & 110 & 100 & 110 \\
\hline 18 & Track & 75 & 77 & 83 & 78 \\
\hline 19 & TLD & 111 & 132 & 120 & 121 \\
\hline 20 & Track & 136 & 138 & 142 & 139 \\
\hline 21 & Bubble & 76 & - & 58 & 67 \\
\hline 22 & TLD-albedo & 77 & 90 & 84 & 84 \\
\hline 23 & Track & 77 & 103 & 84 & 88 \\
\hline 24 & - & & - & - & - \\
\hline $25 A$ & TLD & 99 & 106 & 99 & 101 \\
\hline $25 B$ & TLD-albedo & 101 & 100 & 104 & 102 \\
\hline $25 \mathrm{C}$ & TLD-albedo & 71 & 72 & 67 & 70 \\
\hline 26 & Bubble \& TLD-albedo & 120 & 103 & 124 & 116 \\
\hline 28 & TLD-albedo & 105 & 92 & 96 & 98 \\
\hline 31 & - & - & - & $-\cdot$ & - \\
\hline 33 & Film & 50 & - & 70 & 60 \\
\hline 34 & TLD & - & - & - & - \\
\hline 35 & Track & 70 & 70 & 70 & 70 \\
\hline 37 & TLD-albedo & 71 & 56 & 50 & 59 \\
\hline 38 & TLD & 97 & 97 & 103 & 99 \\
\hline 39 & TILD-albedo & 85 & 87 & 86 & 86 \\
\hline 40 & TLD-aits do & 102 & 134 & 103 & 113 \\
\hline $41 \mathrm{~A}$ & Film & . & - & - & - \\
\hline $41 \mathrm{~B}$ & Track \& TLD-albedo & 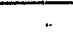 & 70 & - & 70 \\
\hline $41 \mathrm{C}$ & TLD & - & - & - & - \\
\hline $42 \mathrm{~A}$ & TI.D & 136 & 150 & 207 & 164 \\
\hline $42 B$ & TLD-albedo & 103 & 111 & 103 & 105 \\
\hline 43 & TLD & 109 & 111 & 119 & 113 \\
\hline 44 & TLD-albedo & 90 & 80 & 70 & 80 \\
\hline 45 & TLD-albedo & 79 & 84 & 79 & 81 \\
\hline 46 & TLD-albedo & 2.35 & 225 & 205 & 222 \\
\hline $48 \mathrm{~A}$ & TLD-albedo & 122 & 124 & 108 & 118 \\
\hline $48 \mathrm{~B}$ & TLD-albedo & 132 & 138 & 141 & 137 \\
\hline
\end{tabular}

Participants designated by numbers to preserve anonymity.

biackground corrected values as reported by participants.

$c_{10}{ }^{-5} \mathrm{~Sv}=1 \mathrm{mrem}$ 
Table 4. Summary of reported neutron results for PDIS 14, cxposure 2, $15-\mathrm{cm}$ polyethylene-moderated ${ }^{252} \mathrm{Cr}\left({ }^{137} \mathrm{Cs}\right.$ enhanoed $), H_{n}=60\left(10^{-5}\right) \mathrm{Sv}$

\begin{tabular}{|c|c|c|c|c|c|}
\hline \multirow[b]{2}{*}{ Group" } & \multirow{2}{*}{$\begin{array}{l}\text { Neutron dosimeter } \\
\text { type }\end{array}$} & \multicolumn{4}{|c|}{ Neutron dose equivalent ${ }^{b}, 10^{-5} S V^{c}$} \\
\hline & & 1 & 2 & 3 & Average \\
\hline 1 & - & - & - & - & - \\
\hline 2 & Bubble & 51 & - & - & 51 \\
\hline 3 & TLD-albedo & - & 361 & - & 361 \\
\hline 4 & TLD-albedo & 220 & 160 & 250 & 210 \\
\hline 5 & TLD & 234 & 195 & 225 & 218 \\
\hline 6 & Film, Track & 90 & 70 & - & 80 \\
\hline 7 & TLD & 187 & 184 & 193 & 188 \\
\hline 8 & Track & 690 & 480 & 480 & 550 \\
\hline 9 & TLD & 88 & 78 & 84 & 83 \\
\hline 10 & TLD-albedo & 162 & 173 & 189 & 175 \\
\hline 11 & Track & 50 & 50 & 50 & 50 \\
\hline 12 & TLD-albedo & 34 & 47 & 45 & 42 \\
\hline 13 & Film & - & 90 & 90 & 90 \\
\hline $14 \mathrm{~A}$ & TLD & 60 & - & - & 60 \\
\hline $14 \mathrm{~B}$ & TLD-albedo & 44 & $=$ & - & 44 \\
\hline $14 \mathrm{C}$ & Track & 43 & 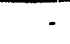 & $\cdot$ & 43 \\
\hline $14 \mathrm{D}$ & Track & 57 & - & - & 57 \\
\hline 16 & TLD-albedo & 94 & 95 & 105 & 98 \\
\hline 17 & TLD-albedo \& Track & so & 40 & 40 & 43 \\
\hline 18 & Track & 57 & 60 & 61 & 59 \\
\hline 19 & TLD & 154 & 156 & 159 & 156 \\
\hline 20 & Track & 101 & 100 & 99 & 100 \\
\hline 21 & Bubble & 54 & 51 & 50 & 52 \\
\hline 22 & TLD-albedo & - & 3 & 3 & 2 \\
\hline 23 & Track & 76 & 87 & 83 & 82 \\
\hline 24 & - & $\cdot$ & - & $\cdot$ & - \\
\hline $25 \mathrm{~A}$ & TLD & 73 & 66 & 67 & 69 \\
\hline $25 B$ & TLD-albedo & 58 & 54 & 55 & 56 \\
\hline $25 \mathrm{C}$ & TLD-albedo & 38 & 52 & 46 & 45 \\
\hline 26 & Bubble \& TLD-albedo & 64 & 73 & 73 & 70 \\
\hline 28 & TLD-albedo & 176 & 87 & 129 & 131 \\
\hline 31 & $\cdot$ & - & - & - & - \\
\hline 33 & Film & 40 & - & - & 40 \\
\hline 34 & TILD & - & - & - & - \\
\hline 35 & Track & 50 & 60 & 60 & 57 \\
\hline 37 & TLD-albedo & 4 & 0 & 2 & 2 \\
\hline 38 & TLD & 192 & 168 & 134 & 165 \\
\hline 39 & TLD-albedo & 67 & 62 & 42 & 57 \\
\hline 40 & TLD-albedo & 89 & 100 & 127 & 105 \\
\hline $41 \mathrm{~A}$ & Film & 20 & - & - & 20 \\
\hline $41 \mathrm{~B}$ & Track \& TLD-albedo & - & - & - & ? \\
\hline $41 \mathrm{C}$ & TLD & . & - & - & - \\
\hline $42 \mathrm{~A}$ & TLD & 104 & 119 & 160 & 128 \\
\hline $42 B$ & TLD-albedo & 30 & 26 & 33 & 30 \\
\hline 43 & TLD & 107 & 103 & 90 & 100 \\
\hline 44 & TLD-albedo & 20 & 30 & 0 & 17 \\
\hline 45 & TT_D-albedo & 245 & 204 & 231 & 227 \\
\hline 46 & TLD-albedo & 60 & 60 & 30 & 50 \\
\hline $48 \mathrm{~A}$ & TLD-albedo & 35 & 42 & 46 & 41 \\
\hline $48 B$ & TLD-albedo & 100 & 100 & 96 & 99 \\
\hline
\end{tabular}

"Participants designated by numbers to preserve anonymity

background corrected values as reported by participants.

$c_{10}^{-5} \mathrm{~Sv}=1 \mathrm{mrem}$. 
Table 5. Summary of reported neutron results for PDIS 14, cxposure 3,

15 -am $\mathrm{D}_{2} \mathrm{O}$-moderatcod ${ }^{252} \mathrm{Cr}, 60^{\circ}$ rotation, perpendicular $H_{n}=258\left(10^{-5}\right) \mathrm{Sv}$

\begin{tabular}{|c|c|c|c|c|c|}
\hline \multirow[b]{2}{*}{ Group" } & \multirow{2}{*}{$\begin{array}{l}\text { Neutron dosimeter } \\
\text { type }\end{array}$} & \multicolumn{4}{|c|}{ Neut is dose equivalent ${ }^{b}, 10^{-5} \mathrm{~Sv}^{c}$} \\
\hline & & 1 & 2 & 3 & Average \\
\hline 1 & - & - & - & - & - \\
\hline 2 & Bubble & 183 & - & - & 183 \\
\hline 3 & TLD-albedo & 576 & 414 & 424 & 471 \\
\hline 4 & TLD-albedo & 240 & 240 & 260 & 247 \\
\hline 5 & TLD & 182 & 195 & 198 & 192 \\
\hline 6 & Film, Track & 220 & 230 & . & 225 \\
\hline 7 & TLD & 258 & 252 & 234 & 248 \\
\hline 8 & Track & 850 & 860 & 960 & 890 \\
\hline 9 & TLD & 232 & 195 & 204 & 210 \\
\hline 10 & TLLD-albedo & 196 & 180 & 190 & 189 \\
\hline 11 & Track & 90 & 80 & 100 & 90 \\
\hline 12 & TLD-albedo & 177 & 152 & 167 & 165 \\
\hline 13 & Film & 350 & 370 & 320 & 347 \\
\hline $14 \mathrm{~A}$ & TLD & 276 & .. & - & 276 \\
\hline $14 B$ & TLD-albedo & 160 & - & - & 160 \\
\hline $14 \mathrm{C}$ & Track & 88 & - & - & 88 \\
\hline $14 D$ & Track & 109 & - & - & 109 \\
\hline 16 & TLD-albedo & 165 & 167 & 172 & 168 \\
\hline 17 & TLD-albedo \& Track & 260 & 260 & 260 & 260 \\
\hline 18 & Track & 85 & 87 & 82 & 85 \\
\hline 19 & TLD & 196 & 215 & 184 & 198 \\
\hline 20 & Track & 454 & 460 & 521 & 478 \\
\hline 21 & Bubble & 93 & 87 & 93 & 91. \\
\hline 22 & TLD-albedo & 154 & 150 & 144 & 149 \\
\hline 23 & Track & 189 & 175 & 224 & 196 \\
\hline 24 & - & - & . & - & $\therefore$ \\
\hline $25 \mathrm{~A}$ & TLD & 185 & 180 & 182 & 182 \\
\hline $25 B$ & TLD-albedo & 202 & 204 & 200 & 202 \\
\hline $25 \mathrm{C}$ & TLD-albedo & 129 & 143 & 137 & 136 \\
\hline 26 & Bubble \& TLD-albedo & 278 & 279 & 255 & 271 \\
\hline 28 & TLD-albedo & 202 & 205 & 187 & 198 \\
\hline 31 & - & - & . & 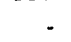 & - \\
\hline 33 & Film & - & 130 & 190 & 160 \\
\hline 34 & TLD & - & - & - & - \\
\hline 35 & Track & 280 & 2600 & 240 & 260 \\
\hline 37 & TLD-albedo & 130 & 148 & 190 & 156 \\
\hline 38 & TLD & 182 & 198 & 175 & 185 \\
\hline 39 & TLD-albedo & 112 & 249 & 179 & 180 \\
\hline 40 & T1LD-albedo & 168 & 187 & 185 & 180 \\
\hline $41 \mathrm{~A}$ & Film & 70 & - & . & 70 \\
\hline $41 \mathrm{~B}$ & Track \& Th.D-albedo & - & 130 & - & 130 \\
\hline $41 \mathrm{C}$ & TLD & - & - & - & - \\
\hline $42 \mathrm{~A}$ & TLLD & 285 & 301 & 276 & 287 \\
\hline $42 B$ & TLD-albedo & 248 & 240 & 278 & 255 \\
\hline 43 & TLD & 283 & - & 291 & 287 \\
\hline 44 & TT.D-albedo & 180 & 180 & 150 & 170 \\
\hline 45 & TLD-albedo & 166 & 152 & 158 & 159 \\
\hline 46 & TLD-albedo & 495 & 590 & 360 & 482 \\
\hline $48 \mathrm{~A}$ & TLD-albedo & 213 & 245 & 239 & 232 \\
\hline $48 B$ & TID-albedo & 264 & 208 & 238 & 237 \\
\hline
\end{tabular}

aparticipants designated by numbers to preserve anonymity.

biackground correcled values as reported by participants.

$c_{1} 0^{-5} \mathrm{~Sv}=1 \mathrm{mrem}$. 
Table 6. Summary of reported neutron results for PDIS 14, exposure 4, $15-\mathrm{cm} D_{2} O$-moderated ${ }^{252} \mathrm{C}$, without cadmium cover on sphere, $H_{n}=263\left(10^{-5}\right) \mathrm{Sv}$

\begin{tabular}{|c|c|c|c|c|c|}
\hline \multirow[b]{2}{*}{ Group ${ }^{2}$} & \multirow{2}{*}{$\begin{array}{l}\text { Neutron dosimeter } \\
\text { type }\end{array}$} & \multicolumn{4}{|c|}{ Neutron dose equivalent ${ }^{b}, 10^{-5} \mathrm{~Sv}^{\mathrm{c}}$} \\
\hline & & 1 & 2 & 3 & Average \\
\hline 1 & - & - & - & - & - \\
\hline 2 & Bubble & 181 & - & - & 181 \\
\hline 3 & TLD-albedo & 674 & 545 & 552 & 590 \\
\hline 4 & TLD-albedo & 510 & 540 & 600 & 550 \\
\hline 5 & ILD & 322 & 331 & 302 & 318 \\
\hline 6 & Film, Track & 880 & 900 & - & 890 \\
\hline 7 & TLD & 518 & 509 & 551 & 526 \\
\hline 8 & Track & 1480 & 1570 & 2080 & 1710 \\
\hline$y$ & TLD & 440 & 417 & 450 & 436 \\
\hline 10 & TLD-albedo & 460 & 414 & 408 & 427 \\
\hline 11 & Track & 200 & 250 & 190 & 213 \\
\hline 12 & TLD-albedo & 267 & 204 & 242 & 238 \\
\hline 13 & Film & 640 & 620 & 650 & 637 \\
\hline $14 \mathrm{~A}$ & TLD & 286 & - & - & 286 \\
\hline $14 \mathrm{~B}$ & TLD-albedo & 217 & - & - & 217 \\
\hline $14 \mathrm{C}$ & Track & 216 & - & - & 216 \\
\hline 14D & Track & 288 & - & - & 288 \\
\hline 16 & TLD-albedo & 321 & 338 & 350 & 336 \\
\hline 17 & TLD-albedo \& Track & 380 & 360 & 380 & 373 \\
\hline 18 & Track & 254 & 241 & 231 & 242 \\
\hline 19 & TLD & 274 & 301 & 271 & 282 \\
\hline 20 & Track & 455 & 460 & 479 & 465 \\
\hline 21 & Bubble & 95 & 99 & 101 & 98 \\
\hline 22 & TLD-albedo & 277 & 244 & 290 & 270 \\
\hline 23 & Track & 312 & 327 & 366 & 335 \\
\hline 24 & - & $\cdot$ & - & - & $\overline{-}$ \\
\hline $25 \mathrm{~A}$ & TLD & 392 & 394 & 377 & 388 \\
\hline $25 \mathrm{~B}$ & TLD-albedo & 401 & 349 & 388 & 379 \\
\hline $25 \mathrm{C}$ & TLD-albedo & 175 & 176 & 182 & 178 \\
\hline 26 & Bubble \& TILD-albedo & 312 & 303 & 318 & 311 \\
\hline 28 & TLD-albedo & 412 & 284 & 290 & 329 \\
\hline 31 & - & - & - & - & - \\
\hline 33 & Film & 150 & 140 & 100 & 130 \\
\hline 34 & TLD & - & - & - & - \\
\hline 35 & Track & 290 & 170 & 290 & 250 \\
\hline 37 & TLD-albedo & 479 & 716 & 588 & 594 \\
\hline 38 & TLD & 414 & 472 & 443 & 443 \\
\hline 39 & TLD-albedo & 271 & 265 & 272 & 269 \\
\hline 40 & TLD-albedo & 314 & 390 & 392 & 36.5 \\
\hline $41 \mathrm{~A}$ & Film & 40 & - & - & 40 \\
\hline $41 B$ & Track \& ITLD-albedo & - & 250 & . & 250 \\
\hline $41 \mathrm{C}$ & TLD & - & - & - & - \\
\hline $42 \mathrm{~A}$ & TLD & 727 & 570 & 673 & 657 \\
\hline $42 B$ & TLD-albedo & 353 & 361 & 335 & 350 \\
\hline 43 & TLD & 296 & 301 & 298 & 298 \\
\hline 44 & TLD-albedo & 240 & 250 & 220 & 237 \\
\hline 45 & TLD-aibedo & 409 & 412 & 394 & 405 \\
\hline 46 & TLD-albedo & 840 & 700 & 820 & 787 \\
\hline $48 \mathrm{~A}$ & TLD-albedo & 350 & 362 & 378 & 36,3 \\
\hline $48 B$ & TLD-albedo & 584 & 505 & 517 & 535 \\
\hline
\end{tabular}

"Participants designated by numbers to preserve anonymity.

biackground corrected values as reported by participants.

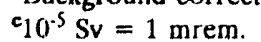


Tabte 7. Summary of reported neutron reaults for PDIS 14, exposure 5 , $15-\mathrm{cm} \mathrm{D}_{2} \mathrm{O}$-moderatod ${ }^{252} \mathrm{CC}, \mathrm{H}_{\mathrm{n}}=258\left(10^{-5} \mathrm{SSv}\right.$

\begin{tabular}{|c|c|c|c|c|c|}
\hline \multirow[b]{2}{*}{ Group } & \multirow{2}{*}{$\begin{array}{l}\text { Neutron dosimetcr } \\
\text { type }\end{array}$} & \multicolumn{4}{|c|}{ Neutron dose equivalent ${ }^{b} 10^{5} \mathrm{~S} v^{e}$} \\
\hline & & 1 & 2 & 3 & Average \\
\hline 1 & - & - & - & - & $\because$ \\
\hline 2 & Bubble & 89 & - & - & 89 \\
\hline 3 & TLD-albedo & 1399 & 978 & ג050 & 1142 \\
\hline 4 & TLD-albedo & 410 & 360 & 390 & 387 \\
\hline 5 & TLD & 303 & 283 & 293 & 293 \\
\hline 6 & Film, Track & 920 & 900 & - & 955 \\
\hline 7 & TLD & 359 & 353 & 343 & 352 \\
\hline 8 & Track & 2030 & 2210 & 2010 & 2083 \\
\hline 9 & TLD & 357 & 306 & 326 & 330 \\
\hline 10 & TLD-albedo & 383 & 335 & 382 & 367 \\
\hline 11 & Track & 200 & 200 & 190 & 197 \\
\hline 12 & TLD-albedo & 221 & 191 & 235 & 216 \\
\hline 13 & Film & 710 & 630 & 660 & 667 \\
\hline $14 \mathrm{~A}$ & TLD & 269 & - & - & 269 \\
\hline $14 \mathrm{~B}$ & TLD-albedo & 273 & - & - & 273 \\
\hline $14 \mathrm{C}$ & Track & 208 & - & - & 208 \\
\hline $14 \mathrm{D}$ & Track & 266 & . & . & 266 \\
\hline 16 & TLD-albedo & 298 & 279 & 267 & 281 \\
\hline 17 & TLD-albedo \& Track & 320 & 320 & 340 & 327 \\
\hline 18 & Track & 220 & 200 & 219 & 213 \\
\hline 19 & TLD & 376 & 359 & 288 & 341 \\
\hline 20 & Track & 466 & 505 & 401 & 457 \\
\hline 21 & Bubble & 117 & 118 & 85 & 107 \\
\hline 22 & TLD-albedo & 258 & 248 & 255 & 254 \\
\hline 23 & Track & 365 & 297 & 298 & 320 \\
\hline 24 & - & - & - & - & - \\
\hline $25 A$ & TLD & 301 & 334 & 304 & 313 \\
\hline $25 B$ & TLD-albedo & 283 & 283 & 295 & 287 \\
\hline $25 \mathrm{C}$ & TLD-albedo & 190 & 190 & 192 & 191 \\
\hline 26 & Bubble \& TLD-albedo & 351 & 304 & 337 & 331 \\
\hline 28 & TLD-albedo & 283 & 286 & 326 & 298 \\
\hline 31 & - & - & - & - & - \\
\hline 33 & Film & 160 & 160 & 130 & 150 \\
\hline 34 & TLD & 187 & 494 & 676 & $4: ; 2$ \\
\hline 35 & Track & 300 & 260 & 300 & 287 \\
\hline 37 & TLD-albedo & 158 & 223 & 207 & 196 \\
\hline 38 & TLD & 272 & 323 & 337 & 311 \\
\hline 39 & TLD-albedo & 226 & 236 & 257 & 240 \\
\hline 40 & TLD-albedo & 349 & 352 & 298 & 333 \\
\hline $41 \mathrm{~A}$ & Film & 9 & - & - & 90 \\
\hline $41 B$ & Track \& TLD-albedo & - & 170 & 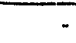 & 170 \\
\hline $41 \mathrm{C}$ & IT.D & - & - & - & - \\
\hline $42 \mathrm{~A}$ & TL.D & 440 & 578 & 432 & 484 \\
\hline $42 \sqrt{3}$ & TLD-albedo & 311 & 331 & 312 & 318 \\
\hline 43 & TI.D & 297 & 328 & 313 & 313 \\
\hline 44 & TI.D-albedo & 250 & 310 & 220 & 260 \\
\hline 45 & TLD-albedo & 248 & 224 & 227 & 233 \\
\hline 46 & TLD-albedo & $5(x)$ & 770 & 810 & 723 \\
\hline $48 \mathrm{~A}$ & TLD-alhedo & 311 & 311 & 289 & 304 \\
\hline $48 \mathrm{~B}$ & TI D-albedo & 387 & 359 & 394 & 380 \\
\hline
\end{tabular}

"Participants designated by numbers to preserve anonymity.

biackground corrected values as reported by participants.

$c_{10}^{-5} \mathrm{~Sv}=1 \mathrm{mrem}$ 
Table 8. Summary of reported neutron resulls for PDIS 14, exposure 6, ${ }^{20} \mathrm{PuBe}, \mathrm{H}_{\mathrm{a}}=44\left(10^{5}\right) \mathrm{Sv}$

\begin{tabular}{|c|c|c|c|c|c|}
\hline \multirow[b]{2}{*}{ Group } & \multirow{2}{*}{$\begin{array}{l}\text { Neutron dosimeter } \\
\text { type }\end{array}$} & \multicolumn{4}{|c|}{ Neutron doese equivalent ${ }^{b}, 10^{5} \mathrm{~Sv}^{0}$} \\
\hline & & 1 & 2 & 3 & Average \\
\hline 1 & - & - & - & 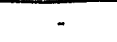 & - \\
\hline 2 & Bubble & 39 & - & - & 39 \\
\hline 3 & TLD-albedo & 17 & 46 & 30 & 31 \\
\hline 4 & TLD-albedo & 74 & 87 & 52 & 71 \\
\hline 5 & TLD & 115 & 76 & 130 & 107 \\
\hline 6 & Film, Track & 44 & 41 & - & 43 \\
\hline 7 & 'TLD & 33 & 57 & 54 & 48 \\
\hline 8 & Track & 340 & 630 & 590 & 520 \\
\hline 9 & TLD & 78 & 78 & 116 & 91 \\
\hline 10 & TLD-albedo & 67 & 40 & 80 & 62 \\
\hline 11 & Track & 50 & 30 & 30 & 37 \\
\hline 12 & TLD-albedo & 54 & 63 & 72 & 63 \\
\hline 13 & Film & - & 60 & 60 & 60 \\
\hline $14 \mathrm{~A}$ & TLD & 61 & - & - & 61 \\
\hline $14 \mathrm{~B}$ & TLD-albedo & 35 & $\therefore$ & - & 35 \\
\hline $14 \mathrm{C}$ & Track & 42 & - & - & 42 \\
\hline $14 D$ & Track & 39 & - & - & 39 \\
\hline 16 & TLD-albedo & 61 & 71 & 76 & 69 \\
\hline 17 & TLD-albedo \& Track & 40 & 40 & 40 & 40 \\
\hline 18 & Track & 55 & 54 & 55 & 55 \\
\hline 19 & TLD & 19 & 24 & 28 & 24 \\
\hline 20 & Track & 50 & 48 & 43 & 47 \\
\hline 21 & Bubble & 37 & 34 & 37 & 36 \\
\hline 22 & Th.D-albedo & 0 & 0 & 0 & 0 \\
\hline 23 & Track & 58 & 50 & 48 & 52 \\
\hline 24 & - & - & - & - & - \\
\hline $25 \mathrm{~A}$ & TLD & 34 & 36 & 33 & 34 \\
\hline $25 \mathrm{~B}$ & TLD-albedo & 35 & 37 & 38 & 37 \\
\hline $25 \mathrm{C}$ & TLD-albedo & 57 & 50 & - & 54 \\
\hline 26 & Bubble \& TLD-albedo & 54 & 44 & 53 & $\begin{array}{l}.50 \\
\end{array}$ \\
\hline 28 & TLD-albedo & 38 & 37 & - & 38 \\
\hline 31 & - & - & - & - & - \\
\hline 33 & Film & 0 & 0 & 0 & 0 \\
\hline 34 & TLD & 0.52 & 0.39 & 0.44 & 0.45 \\
\hline 35 & Track & 50 & 60 & 60 & 57 \\
\hline 37 & TLD-albedo & 0 & 0 & 0 & 0 \\
\hline 38 & TLD & 49 & 14 & 79 & 47 \\
\hline 39 & Tl.D-albedo & 80 & 48 & 64 & 64 \\
\hline 40 & TLD-albedo & 339 & 211 & 281 & 277 \\
\hline $41 \mathrm{~A}$ & Film & 40 & - & - & 40 \\
\hline $41 B$ & Track \& TLD-albedo & - & 230 & - & 230 \\
\hline $41 \mathrm{C}$ & TLD & - & $\cdot$ & $\cdot$ & - \\
\hline $42 \mathrm{~A}$ & TILD & 0 & 0 & 0 & 0 \\
\hline 4.213 & TLD-albedo & $\mathbf{0}$ & 0 & 0 & 0 \\
\hline 43 & TI,D & 113 & 39 & 74 & 75 \\
\hline 44 & TLD-albedo & o & 0 & 0 & 0 \\
\hline 45 & TLD-albedo & 130 & 167 & 149 & 149 \\
\hline 46 & TLD-albedo & 10 & 20 & 10 & 13 \\
\hline $48 \AA$ & TLD-albedo & 0 & 0 & 0 & 0 \\
\hline $48 B$ & Tl_D-albedo & 0 & 0 & 0 & 0 \\
\hline
\end{tabular}

Participants designated by numbers to preserve anonymity.

b Background corrected values as reported by participants.

${ }^{c} 10^{.5} \mathrm{~Sv}=1 \mathrm{mrem}$. 
Table 9. Analysis of reported neutron results for exposure 1, 15-cm $\mathrm{D}_{2} \mathrm{O}$-moderated ${ }^{252} \mathrm{CC}, \mathrm{H}_{\mathrm{n}}=82\left(10^{5}\right) \mathrm{Sv}$

\begin{tabular}{lccc}
\hline $\begin{array}{l}\text { Dosimeter } \\
\text { type }\end{array}$ & $\begin{array}{c}\text { Number of participants } \\
\text { reporting }\end{array}$ & Range & Mormalized results \\
\cline { 4 - 4 }$\pm \sigma$ & 44 & $0.55-8.21$ & $1.51 \pm 1.22$ \\
All & 41 & $0.55-2.93$ & $1.25 \pm 0.48$ \\
Subset $^{b}$ & 9 & $1.20-2.00$ & $1.46 \pm 0.24$ \\
TLD & 19 & $0.72-3.92$ & $1.37 \pm 0.74$ \\
TLD-albedo & 8 & $0.78-8.21$ & $1.93 \pm 2.39$ \\
Track & 3 & $0.73-3.13$ & $2.26 \pm 1.09$ \\
Film & 2 & $0.55-0.82$ & $0.69 \pm 0.14$ \\
Bubble & 3 & $0.85-1.41$ & $1.20 \pm 0.25$ \\
Combination & 4 & & \\
\hline
\end{tabular}

"Reported neutron dose equivalents divided by reference value.

bubset refers to reported data less than three times the reference value. 
Table 10. Analysis of reported neutron results for exposure 2, 15-cm polyethylene moderated ${ }^{252} \mathrm{Cf}\left({ }^{137} \mathrm{Cs}\right.$ enhanced $)$, $\mathrm{H}_{\mathrm{n}}=60\left(10^{\mathrm{s}}\right) \mathrm{Sv}$

\begin{tabular}{lccc}
\hline $\begin{array}{l}\text { Dosimeter } \\
\text { type }\end{array}$ & $\begin{array}{c}\text { Number of participants } \\
\text { reporting }\end{array}$ & Range & Mormalized results \\
\cline { 3 - 4 } All & 44 & $0.03-9.17$ & $1.67 \pm 1.63$ \\
\hline Subset & & $0.03-2.91$ & $1.16 \pm 0.68$ \\
TLD & 38 & $1.00-3.63$ & $2.16 \pm 0.87$ \\
TLD-albedo & 9 & $0.03-6.02$ & $1.57 \pm 1.49$ \\
Track & 19 & $0.72-9.17$ & $2.08 \pm 2.70$ \\
Film & 8 & $0.33-1.50$ & $0.96 \pm 0.48$ \\
Bubble & 4 & $0.85-0.86$ & $0.86 \pm 0.01$ \\
Combination & 2 & $0.72-1.17$ & $0.95 \pm 0.23$ \\
\hline
\end{tabular}

"Reported neutron dose equivalents divided by reference value.

'Subset refers to reported data less than three times the reference value. 
Table 11. Analysis of reported neutron results for exposure 3, $15-\mathrm{cm} \mathrm{D}_{2} \mathrm{O}$-moderated ${ }^{\mathrm{x} 2} \mathrm{Cr}, 60^{\circ}$ rotation, perpendicular $\mathrm{H}_{\mathrm{n}}=258\left(10^{-5}\right) \mathrm{Sv}$

\begin{tabular}{lccc}
\hline $\begin{array}{l}\text { Dosimeter } \\
\text { type }\end{array}$ & $\begin{array}{c}\text { Number of participants } \\
\text { reporting }\end{array}$ & Range & Normalized results \\
\cline { 4 - 4 } & 45 & $0.27-3.45$ & $0.87 \pm 0.53$ \\
All & 44 & $0.27-1.87$ & $0.81 \pm 0.36$ \\
Subset & & $0.71-1.11$ & $0.89 \pm 0.16$ \\
TLD & 9 & $0.53-1.87$ & $0.84 \pm 0.37$ \\
TLD-albedo & 19 & $0.33-3.45$ & $1.06 \pm 1.02$ \\
Track & 8 & $0.27-1.34$ & $0.78 \pm 0.39$ \\
Film & 4 & $0.35-0.71$ & $0.53 \pm 0.18$ \\
Bubble & 2 & $0.50-1.05$ & $0.85 \pm 0.25$ \\
Combination & 3 & & \\
\hline
\end{tabular}

'Reported neutron dose equivalents divided by reference value.

bubset refers to reported data less than three times the reference value. 
Table 12 Analysis of reported neutron results for exposure 4, $15-\mathrm{cm} \mathrm{D}_{2} \mathrm{O}$-moderated ${ }^{25} \mathrm{CC}$, with out cadmium cover on sphere, $H_{n}=263\left(10^{5}\right) S v$

\begin{tabular}{lccc}
\hline $\begin{array}{c}\text { Dosimeter } \\
\text { typc }\end{array}$ & $\begin{array}{c}\text { Number of participants } \\
\text { reporting }\end{array}$ & \multicolumn{2}{c}{ Normalized results } \\
\cline { 3 - 4 } All & 45 & Range & Mean \pm \\
\hline Subset & & $0.15-6.50$ & $1.49 \pm 1.00$ \\
TLD & 43 & $0.15-2.99$ & $1.33 \pm 0.59$ \\
TLD-albedo & 9 & $1.07-2.50$ & $1.53 \pm 0.46$ \\
Track & 19 & $0.68-2.99$ & $1.48 \pm 0.58$ \\
Film & 8 & $0.81-6.50$ & $1.77 \pm 1.81$ \\
Bubble & 4 & $0.15-3.38$ & $1.61 \pm 1.34$ \\
Combination & 2 & $0.37-0.69$ & $0.53 \pm 0.16$ \\
\hline
\end{tabular}

"Reported neutron dose equivalents divided by reference value.

Subset refers to reported data less than three times the reference value. 
Table 13. Analysis of reported neutron results for exposure 5 , $15-\mathrm{cm} \mathrm{D}_{2} \mathrm{O}$-moderated ${ }^{25} \mathrm{Cf}, \mathrm{H}_{\mathrm{a}}=258\left(10^{-5}\right) \mathrm{Sv}$

\begin{tabular}{lccc}
\hline $\begin{array}{l}\text { Dosimeter } \\
\text { type }\end{array}$ & $\begin{array}{c}\text { Number of participants } \\
\text { reporting }\end{array}$ & Range & Normalized results \\
\cline { 4 - 4 } All & 46 & $0.34-8.07$ & $1.44 \pm 1.24$ \\
Subset & Mean & 0 \\
TLD & 43 & $0.34-2.80$ & $1.16 \pm 0.48$ \\
TLD-albedo & 10 & $1.04-1.87$ & $1.34 \pm 0.25$ \\
Track & 19 & $0.74-4.43$ & $1.36 \pm 0.84$ \\
Film & 8 & $0.76-8.07$ & $1.95 \pm 2.33$ \\
But hle & 4 & $0.35-3.70$ & $1.80 \pm 1.40$ \\
Combination & 2 & $0.34-0.41$ & $0.38 \pm 0.03$ \\
\hline
\end{tabular}

Reported neutron dose equivalents divided by reference value.

bubset refers to reported data less than three times the reference value. 
Table 14. Analysis of reported neutron results for exposure 6, ${ }^{20} \mathrm{PuBe}, \mathrm{H}_{\mathrm{v}}=44\left(10^{-5}\right) \mathrm{Sv}$

\begin{tabular}{lccc}
\hline $\begin{array}{l}\text { Dosimeter } \\
\text { type }\end{array}$ & $\begin{array}{c}\text { Number of participants } \\
\text { reporting }\end{array}$ & Range & Mormalized results \\
\cline { 4 - 4 } All & 45 & $0.00-11.82$ & $1.43 \pm 1.97$ \\
Subset & 41 & $0.00-2.43$ & $0.92 \pm 0.59$ \\
TLD & 10 & $0.00-2.43$ & $1.11 \pm 0.77$ \\
TLD-albedo & 19 & $0.00-6.30$ & $1.15 \pm 1.47$ \\
Track & 8 & $0.83-11.82$ & $2.41 \pm 3.56$ \\
Film & 3 & $0.91-1.36$ & $1.08 \pm 0.20$ \\
Bubble & 2 & $0.82-0.89$ & $0.86 \pm 0.03$ \\
Combination & 3 & $0.91-5.23$ & $2.43 \pm 1.98$ \\
\hline
\end{tabular}

'Reported neutron dose equivalents divided by reference value.

Subset refers to reported data less than three times the reference value. 
Table 15. Summary of reportod gamma results for PDIS 14, cxposure 1, $15-\mathrm{cm} \mathrm{D}_{2} \mathrm{O}$-moderated ${ }^{252} \mathrm{C}, \mathrm{H}_{8}=20\left(10^{-5} \mathrm{SV}\right.$

\begin{tabular}{|c|c|c|c|c|c|}
\hline \multirow[b]{2}{*}{ Group } & \multirow{2}{*}{$\begin{array}{c}\text { Gamma dosimeter } \\
\text { type }\end{array}$} & \multicolumn{4}{|c|}{ Gamma dose equivakent ${ }^{b}, 10^{-5} \mathrm{~Sv}^{\mathrm{c}}$} \\
\hline & & 1 & 2 & 3 & Average \\
\hline 1 & TLD-700 & 72 & 78 & 70 & 73 \\
\hline 2 & - & - & - & - & - \\
\hline 3 & $\mathrm{TLD}-\mathrm{Li}_{2} \mathrm{~B}_{4} \mathrm{O}_{7}$ & 14 & 17 & 16 & 16 \\
\hline 4 & TLD- $\mathrm{Li}_{2} \mathrm{~B}_{4} \mathrm{O}_{7}$ & 15 & 16 & 13 & 15 \\
\hline 5 & TLD- $\mathrm{Li},{ }_{2} \mathrm{~B}_{4} \mathrm{O}_{7}$ & 13 & 13 & 13 & 13 \\
\hline 6 & Film & 23 & 22 & 20 . & 22 \\
\hline 7 & TLD $-\mathrm{Li}_{2} \mathrm{~B}_{4} \mathrm{O}_{7}$ & 14 & 15 & 14 & 14 \\
\hline 8 & TLD-BeO & 0 & 0 & 0 & 0 \\
\hline 9 & TLD $-\mathrm{Li}_{2} \mathrm{~B}_{4} \mathrm{O}_{7}$ & 13 & 12 & 12 & 12 \\
\hline 10 & TLD- $\mathrm{Li}_{2} \mathrm{~B}_{4} \mathrm{O}_{7}$ & 12 & 12 & 11 & 12 \\
\hline 11 & TLD-100 & 300 & 300 & 280 & 293 \\
\hline 12 & TLD-700 & 14 & 10 & 11 & 12 \\
\hline 13 & Film & 20 & 20 & 30 & 23 \\
\hline $14 \mathrm{~A}$ & TLD. 700 & 21 & - & - & 21 \\
\hline $14 \mathrm{~B}$ & TLD-700 & 18 & - & - & 18 \\
\hline $14 \mathrm{C}$ & - & - & - & - & - \\
\hline $14 \mathrm{D}$ & . & - & - & - & - \\
\hline 16 & TLD -700 & 14 & 11 & 13 & 13 \\
\hline 17 & Film & 30 & 30 & 20 & 27 \\
\hline 18 & $\mathrm{~T} T \mathrm{D}-\mathrm{Li}_{2} \mathrm{~B}_{4} \mathrm{O}_{7}$ & 21 & 16 & 12 & 16 \\
\hline 19 & TLD-Li ${ }_{2} \mathrm{~B}_{4} \mathrm{O}_{7}$ & 12 & 16 & 15 & 14 \\
\hline 20 & Film & 19 & 19 & 19 & 19 \\
\hline 21 & - & - & - & - & - \\
\hline 22 & TLD $-\mathrm{Li}_{2} \mathrm{~B}_{4} \mathrm{O}_{7}$ & 14 & 14 & 15 & 14 \\
\hline 23 & - & - & - & - & - \\
\hline 24 & TLD-700 & 9 & 8 & 23 & 13 \\
\hline $25 \mathrm{~A}$ & TLD-700 & 18 & 10 & 12 & 13 \\
\hline $25 \mathrm{~B}$ & TLD.700 & 13 & 13 & 13 & 13 \\
\hline $25 \mathrm{C}$ & TLD $-\mathrm{Li}_{2} \mathrm{~B}_{4} \mathrm{O}_{7}$ & 0 & 0 & 0 & 0 \\
\hline 26 & TID.700 & 15 & 19 & 15 & 16 \\
\hline 28 & $\mathrm{Li}_{2} \mathrm{~B}_{4} \mathrm{O}_{7}$ & 19 & 20 & 14 & 18 \\
\hline 31 & TLD-700 & 9 & 10 & 10 & 10 \\
\hline 33 & Film & - & 10 & 10 & 10 \\
\hline 34 & $\mathrm{TLD}^{-\mathrm{CaSO}_{4}}$ & 18 & 15 & 18 & 17 \\
\hline 35 & TLD-700 & 30 & 30 & 30 & 30 \\
\hline 37 & TLD $-\mathrm{Li}_{2} \mathrm{~B}_{4} \mathrm{O}_{7}$ & 0 & 16 & 18 & 11 \\
\hline 38 & TLD $-\mathrm{Li}_{2} \mathrm{~B}_{4} \mathrm{O}_{7}$ & 10 & 9 & 18 & 12 \\
\hline 39 & TLD-700 & 14 & 14 & 15 & 14 \\
\hline 40 & ILD-CaSO & 27 & 22 & 22 & 24 \\
\hline $41 \mathrm{~A}$ & Film & 20 & - & - & 20 \\
\hline $41 B$ & 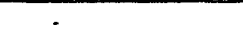 & - & $\cdot$ & - & - \\
\hline $41 \mathrm{C}$ & TLD -700 & . & - & 150 & 150 \\
\hline $42 \mathrm{~A}$ & TILD-100 & 43 & 31 & 18 & 31 \\
\hline $42 \mathrm{~B}$ & TLD -100 & 19 & 26 & 20 & 22 \\
\hline 43 & TID- $\mathrm{Li}_{2}{ }_{2} \mathrm{~B}_{1} \mathrm{O}_{7}$ & 22 & 18 & 15 & 18 \\
\hline 44 & TLD -700 & 10 & 10 & 10 & 10 \\
\hline 45 & TID $-\mathrm{CaSO}_{4}$ & 20 & 17 & 15 & 17 \\
\hline 46 & TLD $-\mathrm{Li}_{2} \mathrm{~B}_{4} \mathrm{O}_{7}$ & 15 & 15 & 15 & 15 \\
\hline $48 \mathrm{~A}$ & TI.D $-\mathrm{Li}_{2} \mathrm{~B}_{4} \mathrm{O}_{7}$ & 38 & 21 & 30 & 30 \\
\hline $48 \mathrm{~B}$ & TILD- $\mathrm{Li}_{2} \mathrm{~B}_{3} \mathrm{O}_{7}$ & 0 & 0 & 0 & 0 \\
\hline
\end{tabular}

"Participants designated by numbers to preserve anonymity.

background corrected values as reported by participants.

$c_{10} 0^{-5} \mathrm{~Sv}=1 \mathrm{mrem}$. 
Table 16. Summary of reported gamma results for PDIS 14, exposure 2 , $15-\mathrm{cm}$ polyethylene moderated ${ }^{252} \mathrm{C}\left({ }^{137} \mathrm{C}\right.$ enhanood $), H_{B}=185\left(10^{-5}\right) \mathrm{Sv}$

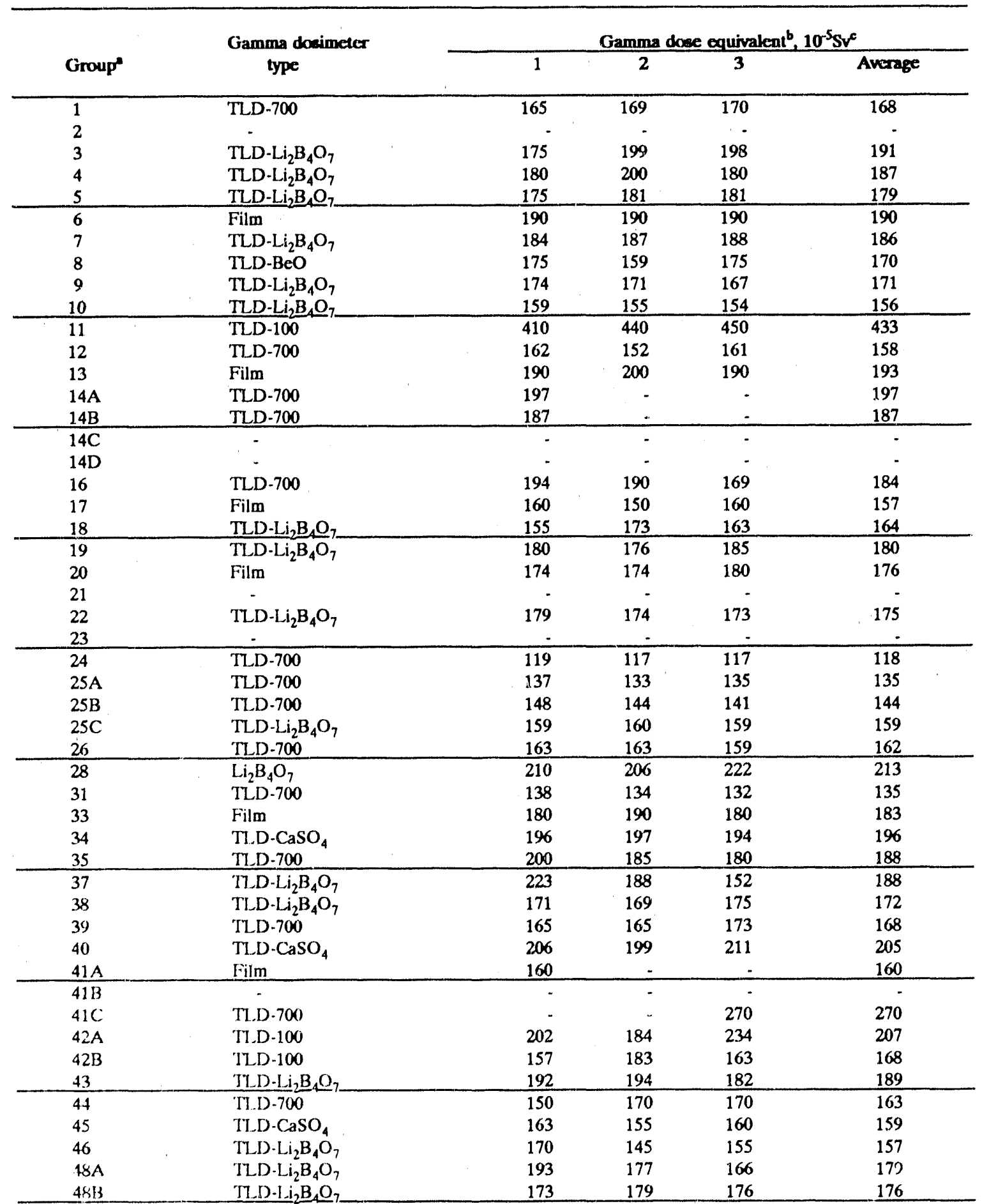

"Participants designated by numbers to preserve anonymity.

${ }^{t}$ i3ackgruund corrected values as reported by participants.

$c_{10^{-5}}$ Sv $=1$ mren. 
Table 17. Summary of reported gamma results for PDIS 14, exposure 3 , $15-\mathrm{cm} \mathrm{D}_{2} \mathrm{O}$-moderated ${ }^{252} \mathrm{C}, 60^{\circ}$ rotation, perpendicular $\mathrm{H}_{\mathrm{B}}=52\left(10^{-5}\right) \mathrm{Sv}$

\begin{tabular}{|c|c|c|c|c|c|}
\hline \multirow[b]{2}{*}{ Group" } & \multirow{2}{*}{$\begin{array}{c}\text { Gamma dosimetcr } \\
\text { type }\end{array}$} & \multicolumn{4}{|c|}{ Gamma dose equivelent ${ }^{b}, 10^{-5} \mathrm{~Sv}^{c}$} \\
\hline & & 1 & 2 & 3 & Average \\
\hline 1 & TLD-700 & 140 & 139 & - & 140 \\
\hline 2 & $\cdot$ & - & - & - & - \\
\hline 3 & TLD $-\mathrm{Li}_{2} \mathrm{~B}_{4} \mathrm{O}_{7}$ & 42 & 49 & 48 & 46 \\
\hline 4 & TLD $-\mathrm{Li}_{2} \mathrm{~B}_{4} \mathrm{O}_{7}$ & 49 & 44 & 40 & 44 \\
\hline 5 & TLD- $\mathrm{Li}_{2} \mathrm{~B}_{4} \mathrm{O}_{7}$ & 43 & 41 & 32 & 39 \\
\hline 6 & Film & 58 & 57 & 55 & 57 \\
\hline 7 & TLD $-\mathrm{Li}_{2} \mathrm{~B}_{4} \mathrm{O}_{7}$ & 45 & 44 & 42 & 44 \\
\hline 8 & TLD-BeO & 43 & 40 & 28 & 37 \\
\hline 9 & TLD- $\mathrm{Li}_{2} \mathrm{~B}_{4} \mathrm{O}_{7}$ & 39 & 48 & 38 & 42 \\
\hline 10 & $\mathrm{TLD}-\mathrm{Li}_{2} \mathrm{~B}_{4} \mathrm{O}_{7}$ & 41 & 36 & 38 & 38 \\
\hline 11 & TLD-100 & 570 & 550 & 580 & 567 \\
\hline 12 & TLD-700 & 42 & 47 & 39 & 43 \\
\hline 13 & Film & 60 & 60 & 60 & 60 \\
\hline $14 \mathrm{~A}$ & TLD -700 & 54 & - & - & 54 \\
\hline $14 \mathrm{~B}$ & TLD-700 & 49 & - & . & 49 \\
\hline $14 \mathrm{C}$ & - & - & - & - & - \\
\hline 14D & - & - & - & - & - \\
\hline 16 & TLD-700 & 42 & 49 & 40 & 44 \\
\hline 17 & Film & 60 & 60 & 60 & 60 \\
\hline 18 & TLD $-\mathrm{Li}_{2} \mathrm{~B}_{4} \mathrm{O}_{7}$ & 46 & 33 & 46 & 42 \\
\hline 19 & TLD $-\mathrm{Li}_{2} \mathrm{~B}_{4} \mathrm{O}_{7}$ & 46 & 51 & 40 & 46 \\
\hline 20 & Film & 64 & 64 & 64 & 64 \\
\hline 21 & - & - & - & - & - \\
\hline 22 & TLD- $\mathrm{Li}_{2} \mathrm{~B}_{4} \mathrm{O}_{7}$ & 42 & 45 & 44 & 44 \\
\hline 23 & - & - & - & - & - \\
\hline 24 & TLD.700 & 30 & 29 & 32 & 30 \\
\hline $25 \mathrm{~A}$ & TLD-700 & 39 & 38 & 37 & 38 \\
\hline $25 B$ & TLD -700 & 41 & 39 & 42 & 41 \\
\hline $25 \mathrm{C}$ & $\mathrm{TZD}-\mathrm{Li}_{2} \mathrm{~B}_{4} \mathrm{O}_{7}$ & 34 & 38 & 32 & 35 \\
\hline 26 & TID. -700 & 43 & 46 & 46 & 45 \\
\hline 28 & $\mathrm{Li}_{2} \mathrm{~B}_{4} \mathrm{O}_{7}$ & 57 & 60 & 62 & 60 \\
\hline 31 & TLD-700 & 30 & 30 & 28 & 29 \\
\hline 33 & Film & 40 & 50 & 50 & 47 \\
\hline 34 & $\mathrm{TLD}_{-\mathrm{CaSO}}$ & 55 & 55 & 57 & 56 \\
\hline 35 & TLD-700 & 65 & 65 & 70 & 67 \\
\hline 37 & TLD-Li ${ }_{2} \mathrm{~B}_{4} \mathrm{O}_{7}$ & 41 & 64 & 54 & 53 \\
\hline 38 & TLD $-\mathrm{Li}_{2} \mathrm{~B}_{4} \mathrm{O}_{7}$ & 45 & 43 & 41 & 43 \\
\hline 39 & TLD -700 & 41 & 47 & 42 & 43 \\
\hline 40 & TLD $\cdot \mathrm{CaSO}_{4}$ & 43 & 55 & 54 & 51 \\
\hline $41 \mathrm{~A}$ & Film & 50 & - & - & 50 \\
\hline $41 \mathrm{~B}$ & - & - & $\cdot$ & - & - \\
\hline $41 \mathrm{C}$ & TLD-700 & - & - & 100 & 100 \\
\hline $42 \mathrm{~A}$ & TLD 100 & 47 & 59 & 93 & 66 \\
\hline $42 B$ & TLD-100 & 55 & 59 & 63 & 59 \\
\hline 43 & TID-L ${ }_{2} \mathrm{~B}_{4} \mathrm{O}_{7}$ & 45 & - & 47 & 46 \\
\hline 44 & TLD-700 & 50 & 40 & 40 & 43 \\
\hline 45 & TLD $\cdot \mathrm{CaSO}_{4}$ & 54 & 46 & 54 & 51 \\
\hline 46 & TLD $-\mathrm{Li}_{2} \mathrm{~B}_{4} \mathrm{O}_{7}$ & 45 & 35 & 45 & 42 \\
\hline $48 \mathrm{~A}$ & TLD-Li ${ }_{2} \mathrm{~B}_{4} \mathrm{O}_{7}$ & 35 & 36 & 43 & 38 \\
\hline $48 B$ & TLD $-\mathrm{Li}_{2} \mathrm{~B}_{4} \mathrm{O}_{7}$ & 22 & 34 & 40 & 32 \\
\hline
\end{tabular}

"Participants designated by numbers to preserve anonymity.

Background corrected values as reported by participants.

$c_{10}^{-5} \mathrm{SV}=1 \mathrm{mrem}$. 
Table 18. Summsry of neported gamma results for PDIS 14, exposure 4, $15-\mathrm{cm} \mathrm{D}_{2} \mathrm{O}$-moderated ${ }^{252} \mathrm{C}$, without cadmium cover on sphere, $\mathrm{H}_{\mathrm{B}}=42\left(10^{-5}\right) \mathrm{Sv}$

\begin{tabular}{|c|c|c|c|c|c|}
\hline \multirow[b]{2}{*}{ Group } & \multirow{2}{*}{$\begin{array}{c}\text { Gamma dosimeter } \\
\text { type }\end{array}$} & \multicolumn{4}{|c|}{ Gamma dose equivakent ${ }^{b}, 10^{-5} \mathrm{~Sv}$} \\
\hline & & 1 & 2 & 3 & Average \\
\hline 1 & TLD-700 & 261 & 261 & 256 & 259 \\
\hline 2 & - & - & - & - & $\cdot$ \\
\hline 3 & TLD- $\mathrm{L}_{2} \mathrm{~B}_{4} \mathrm{O}_{7}$ & 48 & 45 & 46 & 46 \\
\hline 4 & TLD $-\mathrm{Li}_{2} \mathrm{~B}_{4} \mathrm{O}_{7}$ & 38 & 38 & 41 & 39 \\
\hline 5 & TLD-Li ${ }_{2} \mathrm{~B}_{4} \mathrm{O}_{7}$ & 44 & 42 & 43 & 43 \\
\hline 6 & Film & 64 & 62 & 60 & 62 \\
\hline 7 & TL.D $-\mathrm{Li}_{2} \mathrm{~B}_{4} \mathrm{O}_{7}$ & 39 & 37 & 41 & 39 \\
\hline 8 & TLD-BeO & 38 & 34 & 42 & 38 \\
\hline 9 & TLD- $\mathrm{Li}_{2} \mathrm{~B}_{4} \mathrm{O}_{7}$ & 41 & 36 & 35 & 37 \\
\hline 10 & $\mathrm{TLD}-\mathrm{Li}_{2} \mathrm{~B}_{4} \mathrm{O}_{7}$ & 38 & 38 & 36 & 37 \\
\hline 11 & TLD-100 & 900 & 970 & 930 & 933 \\
\hline 12 & TLD.700 & 42 & 32 & 39 & 38 \\
\hline 13 & Film & 70 & 70 & 70 & 70 \\
\hline $14 \mathrm{~A}$ & TLD-700 & 40 & - & - & 40 \\
\hline $14 \mathrm{~B}$ & TLD-700 & 47 & - & - & 47 \\
\hline $14 \mathrm{C}$ & - & - & - & - & - \\
\hline $14 \mathrm{D}$ & - & - & - & - & - \\
\hline 16 & TLD.700 & 45 & 41 & 43 & 43 \\
\hline 17 & Film & 60 & 60 & 60 & 60 \\
\hline 18 & TLD- $\mathrm{Li}_{2} \mathrm{~B}_{4} \mathrm{O}_{7}$ & 39 & 41 & 50 & 43 \\
\hline 19 & TLD- $\mathrm{Li}_{2} \mathrm{~B}_{4} \mathrm{O}_{7}$ & 37 & 37 & 37 & 37 \\
\hline 20 & Film & 64 & 64 & 64 & 64 \\
\hline 21 & - & - & - & - & - \\
\hline 22 & TLD- $\mathrm{Li}_{2} \mathrm{~B}_{4} \mathrm{O}_{7}$ & 47 & 50 & 40 & 46 \\
\hline 23 & $-2^{4}$ & - & - & - & - \\
\hline 24 & TLD-700 & 34 & 44 & 41 & 40 \\
\hline $25 \mathrm{~A}$ & TLD -700 & 35 & 38 & 37 & 37 \\
\hline $25 B$ & TLD-700 & 31 & 37 & 38 & 35 \\
\hline $25 \mathrm{C}$ & TLD $-\mathrm{Li}_{2} \mathrm{~B}_{4} \mathrm{O}_{7}$ & 36 & 34 & 32 & 34 \\
\hline 26 & TLD-700 & 43 & 46 & 41 & 43 \\
\hline 28 & $\mathrm{Li}_{2} \mathrm{~B}_{4} \mathrm{O}_{7}$ & 56 & 58 & 64 & 59 \\
\hline 31 & TLD-700 & 28 & 25 & 28 & 27 \\
\hline 33 & Film & 50 & 60 & 50 & 53 \\
\hline 34 & TLD-CaSO ${ }_{4}$ & 61 & 54 & 55 & 57 \\
\hline 35 & TLD. 700 & 70 & 85 & 95 & 83 \\
\hline 37 & TLD $-\mathrm{Li}_{2} \mathrm{~B}_{4} \mathrm{O}_{7}$ & 46 & 49 & 62 & 52 \\
\hline 38 & TLD $-\mathrm{Li}_{2} \mathrm{~B}_{4} \mathrm{O}_{7}$ & 35 & 49 & 34 & 39 \\
\hline 39 & TLD -700 & 41 & 40 & 41 & 44 \\
\hline 40 & TLD-CaSO 4 & 53 & 45 & 50 & 49 \\
\hline $41 \mathrm{~A}$ & Film & 60 & - & - & 60 \\
\hline $41 B$ & - & - & - & - & - \\
\hline $41 C$ & TID-700 & - & - & 650 & 650 \\
\hline $42 \mathrm{~A}$ & TLD-100 & 54 & 41 & $i 69$ & 88 \\
\hline $42 B$ & TLLD-100 & 77 & 73 & 73 & 74 \\
\hline 43 & $T L D-L_{2}{ }_{2}{ }_{3} O_{7}$ & 46 & 47 & 43 & 45 \\
\hline 44 & TLD -700 & 30 & 40 & 40 & 37 \\
\hline 45 & TID-CaSO & 56 & 54 & 60 & 57 \\
\hline 46 & TLD-L $\mathrm{i}_{2} \mathrm{~B}_{4} \mathrm{O}_{7}$ & 40 & 20 & 35 & 32 \\
\hline $48 \mathrm{~A}$ & TLD $-\mathrm{Li}_{2} \mathrm{~B}_{4}^{4} \mathrm{O}_{7}$ & 49 & 39 & 50 & 46 \\
\hline $48 \mathrm{~B}$ & $\mathrm{TI}, \mathrm{D}-\mathrm{Li}{ }_{2} \mathrm{~B}_{4} \mathrm{O}_{7}$ & 51 & 55 & 45 & 50 \\
\hline
\end{tabular}

- Participants designated by numb:rs to preserve anonymity.

background corrected values as reported by participants.

$10^{-5} \mathrm{~Sv}=1 \mathrm{mrem}$. 
Table 19. Summary of reported gamma reaults for PDIS 14, cxpowure S, $15-\mathrm{cm} \mathrm{D} \mathrm{D}_{2} \mathrm{O}$-moderatod ${ }^{22} \mathrm{Cr}, \mathrm{H}_{\mathrm{B}}=52\left(10^{-5}\right) \mathrm{Sv}$

\begin{tabular}{|c|c|c|c|c|c|}
\hline \multirow[b]{2}{*}{ Group" } & \multirow{2}{*}{$\begin{array}{c}\text { Gamma docimeter } \\
\text { type }\end{array}$} & \multicolumn{4}{|c|}{ Gamma dose equivalent ${ }^{b}, 10^{-5} \mathrm{~S}$} \\
\hline & & 1 & 2 & 3 & Average \\
\hline 1 & TLD-700 & 42 & 42 & 43 & 42 \\
\hline 2 & - & - & - & - & - \\
\hline 3 & TILD-L $\mathrm{i}_{2} \mathrm{~B}_{4} \mathrm{O}_{7}$ & 48 & 52 & 55 & 52 \\
\hline 4 & TLD-L $\mathrm{i}_{2} \mathrm{~B}_{4} \mathrm{O}_{7}$ & 48 & 46 & 44 & 46 \\
\hline 5 & TLD $-\mathrm{Li}_{2} \mathrm{~B}_{4} \mathrm{O}_{7}$ & 50 & 47 & 43 & 47 \\
\hline 6 & Film & 68 & 68 & 61 & 66 \\
\hline 7 & TZD-Li ${ }_{2} \mathrm{~B}_{4} \mathrm{O}_{7}$ & 44 & 45 & 44 & 44 \\
\hline 8 & TLD-BeO & 44 & 33 & 46 & 41 \\
\hline 9 & TZD $-\mathrm{Li}_{2} \mathrm{~B}_{4} \mathrm{O}_{7}$ & 41 & 42 & 42 & 42 \\
\hline 10 & TLD-Li ${ }_{2} \mathrm{~B}_{3} \mathrm{O}_{7}$ & 40 & 41 & 45 & 42 \\
\hline 11 & TLD-100 & 780 & 760 & 720 & 753 \\
\hline 12 & TLD-700 & 45 & 43 & 47 & 45 \\
\hline 13 & Film & 80 & 70 & 70 & 73 \\
\hline $14 \mathrm{~A}$ & TLD-700 & 53 & . & - & 53 \\
\hline 1413 & TID. 700 & 44 & - & - & 44 \\
\hline $14 \mathrm{C}$ & - & $\cdot$ & - & - & $\cdot$ \\
\hline $14 \mathrm{D}$ & - & $\cdot$ & - & $\cdot$ & - \\
\hline 16 & TLD-700 & 44 & 44 & 44 & 44 \\
\hline 17 & Film & 70 & 60 & 60 & 63 \\
\hline 18 & TID- $\mathrm{Li}_{2} \mathrm{~B}_{4} \mathrm{O}_{7}$ & 49) & 52 & 41 & 47 \\
\hline 19 & TLD $-\mathrm{Li}_{2} \mathrm{~B}_{4} \mathrm{O}_{7}$ & 46 & 40 & 47 & 44 \\
\hline 20 & Film & 71 & 77 & 71 & 73 \\
\hline 21 & • & $\cdot$ & - & - & - \\
\hline 22 & TLD $-\mathrm{Li}_{2} \mathrm{~B}_{4} \mathrm{O}_{7}$ & 49 & 44 & 47 & 47 \\
\hline 23 & & - & - & & - \\
\hline 24 & TLD -700 & 38 & 34 & 47 & 40 \\
\hline $25 \mathrm{~A}$ & THDD-700 & 44 & 47 & 43 & 45 \\
\hline $25 B$ & TLD-700) & 39 & 41 & 41 & 40 \\
\hline $25 \mathrm{C}$ & TLD $-\mathrm{Li}_{2} \mathrm{~B}_{4} \mathrm{O}_{7}$ & 32 & 37 & 42 & 37 \\
\hline 26 & TLD-700 & 47 & 45 & 45 & 46 \\
\hline 28 & $\mathrm{Li}_{2} \mathrm{~B}_{4} \mathrm{O}_{7}$ & 56 & 67 & 55 & 59 \\
\hline 31 & TLD-700 & 32 & 32 & 32 & 32 \\
\hline 33 & Film & 60 & 50 & 70 & 60 \\
\hline 34 & TI.D-CaSO & 850 & 806 & 810 & 822 \\
\hline 35 & TLD 700 & 90 & 80 & 85 & 85 \\
\hline 37 & TLD $-\mathrm{Li}_{2} \mathrm{~B}_{4} \mathrm{O}_{7}$ & 83 & 54 & 57 & 65 \\
\hline 38 & TLD- $\mathrm{Li}_{2} \mathrm{~B}_{4} \mathrm{O}_{7}$ & 42 & 46 & 51 & 46 \\
\hline 39 & TLD -700 & 48 & 45 & 47 & 47 \\
\hline 40 & $\mathrm{TLD}-\mathrm{CaSO}_{4}$ & 55 & 60 & 58 & 58 \\
\hline $41 \mathrm{~A}$ & Film & 60 & . & - & 60 \\
\hline $41 B$ & - & - & - & $\cdot$ & - \\
\hline $41 C$ & TLD-700 & - & - & 410 & 410 \\
\hline $42 A$ & TILD-100) & 73 & 96 & 64 & 78 \\
\hline $42 B$ & ILD-100 & 75 & 79 & 70 & 75 \\
\hline 43 & TI.D-Li, $\mathrm{B}_{4} \mathrm{O}_{7}$ & 53 & 46 & 46 & 48 \\
\hline 44 & TLD-700 & 40 & 50 & 40 & 43 \\
\hline 45 & TLD $\cdot \mathrm{CaSO}_{4}$ & 52 & 53 & 59 & 55 \\
\hline 46 & ILD-L $\mathrm{L}_{2} \mathrm{~B}_{4} \mathrm{O}_{7}$ & 45 & 45 & 40 & 43 \\
\hline $48 \AA$ & TLD $-\mathrm{Li}_{2} \mathrm{~B}_{4} \mathrm{O}_{7}$ & 40 & 66 & 44 & 50 \\
\hline $48 B$ & $\mathrm{~T} Z \mathrm{D}-\mathrm{L}_{2} \mathrm{~B}_{4} \mathrm{~B}_{7}$ & 6,3 & 55 & 46 & 55 \\
\hline
\end{tabular}

"Participants designated by numbers to preserve anonymity.

Background corrected values as reported by participants.

${ }^{c_{1}} 10^{-5} \mathrm{~Sv}=1 \mathrm{mrcm}$. 
Table 20. Summary of reported gamma results for PDIS 14, exposure 6, ${ }^{20 P u B e}, H_{B}=1\left(10^{-5}\right) S v$

\begin{tabular}{|c|c|c|c|c|c|}
\hline \multirow[b]{2}{*}{ Group } & \multirow{2}{*}{$\begin{array}{c}\text { Gamma doaimeter } \\
\text { type }\end{array}$} & \multicolumn{4}{|c|}{ Gamma dose equivalent ${ }^{b}, 10^{-5} \mathrm{~Sv}^{c}$} \\
\hline & & 1 & 2 & 3 & Average \\
\hline 1 & TLD-700 & 5 & 4 & 5 & 5 \\
\hline 2 & - & - & - & - & - \\
\hline 3 & TLD- $\mathrm{Li}_{2} \mathrm{~B}_{4} \mathrm{O}_{7}$ & 2 & 2 & 2 & 2 \\
\hline 4 & TLD- $\mathrm{Li}_{2} \mathrm{~B}_{4} \mathrm{O}_{7}$ & 2 & 2 & 2 & 2 \\
\hline 5 & TLD- $\mathrm{Li}_{2} \mathrm{~B}_{4} \mathrm{O}_{7}$ & 3 & 3 & 3 & 3 \\
\hline 6 & Film & 10 & 10 & 10 & 10 \\
\hline 7 & $\mathrm{TLD} \cdot \mathrm{Li}_{2} \mathrm{~B}_{4} \mathrm{O}_{7}$ & 3 & 2 & 2 & 2 \\
\hline 8 & TLD-BëO & $\mathbf{0}$ & 0 & 0 & 0 \\
\hline 9 & TLD- $\mathrm{Li}_{2} \mathrm{~B}_{4} \mathrm{O}_{7}$ & 3 & 2 & 2 & 2 \\
\hline 10 & TLD-Li ${ }_{2} \mathrm{~B}_{4} \mathrm{O}_{7}$ & 0 & 0 & 1 & 0 \\
\hline 11 & TLD-100 & 20 & 20 & 20 & 20 \\
\hline 12 & TLD-700 & 0 & 1 & 0 & 0 \\
\hline 13 & Film & 0 & 0 & 0 & 0 \\
\hline $14 \mathrm{~A}$ & TLD-700 & 3 & - & - & 3 \\
\hline $14 B$ & TLD.700 & 2 & - & - & 2 \\
\hline $14 C$ & - & - & - & $\cdot$ & - \\
\hline $14 \mathrm{D}$ & - & - & - & - & - \\
\hline 16 & TLD-700 & 0 & 0 & 1 & 0 \\
\hline 17 & Film & 10 & 10 & 10 & 10 \\
\hline 18 & TLD $-\mathrm{Li}_{2} \mathrm{~B}_{4} \mathrm{O}_{7}$ & 0 & 0 & 0 & 0 \\
\hline 19 & TLD $-\mathrm{Li}_{2} \mathrm{~B}_{4} \mathrm{O}_{7}$ & 2 & 3 & 1 & 2 \\
\hline 20 & Film & 0 & 0 & 0 & 0 \\
\hline 21 & - & - & - & - & - \\
\hline 22 & TLD $-\mathrm{Li}_{2} \mathrm{~B}_{4} \mathrm{O}_{7}$ & 2 & 2 & 2 & 2 \\
\hline 23 & $\therefore$ & - & - & - & - \\
\hline 24 & TLD-700 & 2 & 0 & 3 & 2 \\
\hline $25 \mathrm{~A}$ & TLD.790 & 0 & 0 & 0 & 0 \\
\hline $25 B$ & TLD-700 & 0 & 0 & 0 & 0 \\
\hline $25 \mathrm{C}$ & TLD-I $\mathrm{i}_{2} \mathrm{~B}_{4} \mathrm{O}_{7}$ & 0 & 0 & 0 & 0 \\
\hline 26 & TLD-700 & 2 & 2 & 2 & 2 \\
\hline 28 & $\mathrm{Li}_{2} \mathrm{~B}_{4} \mathrm{O}_{7}$ & 2 & 3 & 3 & 3 \\
\hline 31 & TLD-700 & 1 & 1 & 1 & 1 \\
\hline 33 & Film & 0 & 0 & 0 & 0 \\
\hline 34 & TLD-CaSO 4 & 253 & 247 & 242 & 247 \\
\hline 35 & TLD-700 & 0 & 0 & 0 & $\underline{0}$ \\
\hline 37 & TLD $-\mathrm{Li}_{2} \mathrm{~B}_{4} \mathrm{O}_{7}$ & 54 & 0 & 10 & 21 \\
\hline 38 & TLD $-\mathrm{Li}_{2} \mathrm{~B}_{4} \mathrm{O}_{7}$ & 6 & 6 & 0 & 4 \\
\hline 39 & TLD-700 & 1 & 1 & 2 & 1 \\
\hline 40 & TLD-CaSO & 0 & 0 & 0 & 0 \\
\hline 41A & Film & 0 & 0 & 0 & 0 \\
\hline $41 B$ & - & - & - & - & $\dot{ }$ \\
\hline $41 \mathrm{C}$ & TLD-700 & 0 & 0 & 0 & 0 \\
\hline $42 \mathrm{~A}$ & TLD-100 & 0 & 0 & 0 & 0 \\
\hline $42 B$ & TI.D-100 & 0 & 0 & 0 & 0 \\
\hline 43 & TID- $\mathrm{Li}_{2} \mathrm{~B}_{4} \mathrm{O}_{7}$ & 4 & 4 & 6 & 5 \\
\hline 44 & TLD.700 & 10 & 10 & 10 & 10 \\
\hline 45 & TLD-CaSO 4 & 0 & 0 & 0 & 0 \\
\hline 46 & TLD- $-\mathrm{Li}_{2} \mathrm{~B}_{4} \mathrm{O}_{7}$ & 0 & 0 & 0 & 0 \\
\hline $48 A$ & TLD-Li ${ }_{2} \mathrm{~B}_{4} \mathrm{O}_{7}$ & 0 & 0 & 0 & $\mathbf{0}$ \\
\hline $48 \mathrm{~B}$ & TID-Lij ${ }_{2} \mathrm{~B}_{4} \mathrm{O}_{7}$ & 0 & 0 & 0 & 0 \\
\hline
\end{tabular}

Participants designated by numbers to preserve anonymity.

background corrected values as reported by participants.

$\mathrm{c}_{10^{-5}} \mathrm{~Sv}=1 \mathrm{mrem}$. 
Table 21. Analysis of reported gamma results for exposure 1, $15-\mathrm{cm} \mathrm{D} 2 \mathrm{O}$-moderated ${ }^{252} \mathrm{CF}, \mathrm{H}_{\mathrm{B}}=20\left(10^{-5}\right) \mathrm{Sv}$

\begin{tabular}{lccc}
\hline $\begin{array}{l}\text { Dosimetcr } \\
\text { type }\end{array}$ & $\begin{array}{c}\text { Number of participants } \\
\text { reporting }\end{array}$ & \multicolumn{2}{c}{ Normalized results } \\
\hline All & 42 & Range & Mcan \pm \\
Subset & & $0.00-14.67$ & $1.38 \pm 2.36$ \\
TLD-100 & 39 & $0.00-1.53$ & $0.83 \pm 0.30$ \\
TLD-700 & 3 & $1.08-14.67$ & $5.76 \pm 6.30$ \\
TLD-BeO & 14 & $0.48-7.50$ & $1.45 \pm 1.85$ \\
TLD-CaSO & 0 & $0.00-0.00$ & $0.00 \pm 0.00$ \\
TLD- $\mathrm{Li}_{2} \mathrm{~B}_{4} \mathrm{O}_{7}$ & 3 & $0.86-1.18$ & $0.97 \pm 0.15$ \\
Film & 16 & $0.00-1.48$ & $0.72 \pm 0.28$ \\
\hline
\end{tabular}

"Reported gamma dose equivalents divided by reference value.

bubset refers to reported data less than three times the reference value. 
Table 22. Analysis of reported gamma results for exposurc 2, 15-cm polyethylene moderated ${ }^{22} \mathrm{Cf},\left({ }^{137} \mathrm{Cs}\right.$ enhanced $)$, $\mathrm{H}_{\mathrm{B}}=185\left(10^{5}\right) \mathrm{SV}$

\begin{tabular}{|c|c|c|c|}
\hline \multirow{2}{*}{$\begin{array}{l}\text { Dosimeter } \\
\text { type }\end{array}$} & \multirow{2}{*}{$\begin{array}{l}\text { Number of participants } \\
\text { reporting }\end{array}$} & \multicolumn{2}{|c|}{ Normalized results } \\
\hline & & Range & Mcan $\pm \sigma$ \\
\hline All & 44 & $0.64-2.34$ & $0.98 \pm 0.24$ \\
\hline Subset ${ }^{b}$ & 44 & $0.64-2.34$ & $0.98 \pm 0.24$ \\
\hline TLD-100 & 3 & $0.91-2.34$ & $1.46 \pm 0.63$ \\
\hline TLD-700 & 14 & $0.64-1.46$ & $0.92 \pm 0.19$ \\
\hline TLD-BeO & 1 & $0.92-0.92$ & $0.92 \pm 0.00$ \\
\hline $\mathrm{TLD}^{-\mathrm{CaSO}_{4}}$ & 3 & $0.86-1.11$ & $1.01 \pm 0.11$ \\
\hline TLD- $\mathrm{Li}_{2} \mathrm{~B}_{4} \mathrm{O}_{7}$ & 17 & $0.84-1.15$ & $0.96 \pm 0.08$ \\
\hline Film & 6 & $0.85-1.05$ & $0.96 \pm 0.08$ \\
\hline
\end{tabular}

"Reported gamma dose equivalents divided by reference value.

Subset refers to reported data less than three times the reference value. 
Table 23. Analysis of reported gamma results for cxposure 3, $15-\mathrm{cm} \mathrm{D}_{2} \mathrm{O}$-moderated ${ }^{252} \mathrm{Cr}, 60^{\circ}$ rotation, perpendicular $\mathrm{H}_{\mathrm{B}}=52\left(10^{5}\right) \mathrm{Sy}$

\begin{tabular}{lccc}
\hline $\begin{array}{l}\text { Dosimeter } \\
\text { type }\end{array}$ & $\begin{array}{c}\text { Number of participants } \\
\text { reporting }\end{array}$ & \multicolumn{2}{c}{ Normalized results } \\
\cline { 4 - 4 } & 44 & Range & Mean \pm o \\
\hline All & 43 & $0.56-10.90$ & $1.19 \pm 1.52$ \\
Subset $^{b}$ & 3 & $1.13-10.90$ & $0.96 \pm 0.35$ \\
TLD-100 & 14 & $0.56-2.68$ & $4.44 \pm 4.57$ \\
TLD-700 & 1 & $0.71-0.71$ & $1.05 \pm 0.56$ \\
TLD-BeO & 3 & $0.97-1.07$ & $0.71 \pm 0.00$ \\
TLD-CaSO & 17 & $0.62-1.15$ & $1.01 \pm 0.04$ \\
TLD-Li ${ }_{2} \mathrm{~B}_{4} \mathrm{O}_{7}$ & 6 & $0.90-1.23$ & $0.83 \pm 0.12$ \\
Film & 17 & $1.08 \pm 0.11$ \\
\hline
\end{tabular}

"Reported gamma dose equivalents divided by reference value.

bubset refers to reported data less than three times the reference value. 
Table 24. Analysis of reported gamma results for exposure 4, $15-\mathrm{cm} \mathrm{D}_{2} \mathrm{O}$-moderated ${ }^{252} \mathrm{Cf}$, without cadmium cover on sphere, $\mathrm{H}_{\mathrm{z}}=42\left(10^{5}\right) \mathrm{Sv}$

\begin{tabular}{lccc}
\hline \multirow{2}{*}{$\begin{array}{c}\text { Dosimeter } \\
\text { type }\end{array}$} & $\begin{array}{c}\text { Number of participants } \\
\text { reporting }\end{array}$ & \multicolumn{2}{c}{ Normalized results" } \\
\cline { 4 - 4 } All & 44 & Range & Mean \pm \\
Subset & 41 & $0.64-22.22$ & $2.06 \pm 3.82$ \\
TLD-100 & 3 & $0.64-2.10$ & $1.14 \pm 0.32$ \\
TLD-700 & 14 & $1.77-22.22$ & $8.70 \pm 9.56$ \\
TLD-BeO & 1 & $0.64-15.48$ & $2.41 \pm 3.87$ \\
TLD-CaSO & 3 & $0.90-0.90$ & $0.90 \pm 0.00$ \\
TLD- $\mathrm{Li}_{2} \mathrm{~B}_{4} \mathrm{O}_{7}$ & 17 & $1.17-1.35$ & $1.29 \pm 0.08$ \\
Film & 6 & $0.75-1.41$ & $1.02 \pm 0.16$ \\
\hline
\end{tabular}

"Reported gamma dose equivalents divided by reference value.

Subset refers to reported data less than three times the reference value. 
Table 25. Analysis of reported gamma results for exposure 5, 15-cm $\mathrm{D}_{2} \mathrm{O}$-moderated ${ }^{252} \mathrm{Cf}, \mathrm{H}_{3}=52\left(10^{-5}\right) \mathrm{Sv}$

\begin{tabular}{lccc}
\hline $\begin{array}{l}\text { Dosimeter } \\
\text { type }\end{array}$ & $\begin{array}{c}\text { Number of participants } \\
\text { reporting }\end{array}$ & \multicolumn{2}{c}{ Normalized results } \\
\cline { 4 - 4 } All & 44 & $0.62-15.81$ & Mean $\pm \sigma$ \\
\hline Subset & & $0.62-1.63$ & $1.80 \pm 3.10$ \\
TLD-100 & 41 & $1.44-14.49$ & $1.00 \pm 0.23$ \\
TLD-700 & 3 & $0.62-7.88$ & $5.81 \pm 6.14$ \\
TLD-BeO & 14 & $0.79-0.79$ & $1.40 \pm 1.81$ \\
TLD-CaSO & 1 & $1.05-15.81$ & $0.79 \pm 0.00$ \\
TLD- $\mathrm{Li}_{2} \mathrm{~B}_{4} \mathrm{O}_{7}$ & 3 & $0.71-1.24$ & $5.99 \pm 6.94$ \\
Film & 17 & $1.15-1.41$ & $0.92 \pm 0.13$ \\
\hline
\end{tabular}

"Reported gamma dose equir alents divided by reference value.

'Subset refers to reported data less than three times the reference value. 
Table 26. Analysis of reported gamma results for exposure 6, ${ }^{20} \mathrm{PuBe}, \mathrm{H}_{8}=1\left(10^{-5}\right) \mathrm{Sv}$

\begin{tabular}{lccc}
\hline $\begin{array}{l}\text { Dosimeter } \\
\text { type }\end{array}$ & $\begin{array}{c}\text { Number of participants } \\
\text { reporting }\end{array}$ & Range & Normalized results \\
\hline All & 34 & $0.00-21.33$ & $3.38 \pm 5.12$ \\
Subset $^{b}$ & 24 & $0.00-2.67$ & $1.00 \pm 0.98$ \\
TLD-100 & 3 & $0.00-20.00$ & $6.67 \pm 9.43$ \\
TLD-700 & 11 & $0.00-10.00$ & $2.37 \pm 2.73$ \\
TLD-BeO & 0 & $0.00-0.00$ & $0.00 \pm 0.00$ \\
TLD-CaSO & 2 & $0.00-0.00$ & $0.00 \pm 0.00$ \\
TLD-Li ${ }_{2} \mathrm{~B}_{4} \mathrm{O}_{7}$ & 16 & $0.00-21.33$ & $3.04 \pm 4.92$ \\
Film & 2 & $10.00-10.00$ & $10.00 \pm 0.00$ \\
\hline
\end{tabular}

"Reported gamma dose equivalents divided by reference value.

'Subset refers to reported data less than three times the reference value. 
Table 27. Analysis of total dose equivalent for PDIS 14 exposures

\begin{tabular}{cccccc}
\hline \multirow{2}{*}{$\begin{array}{l}\text { Exposure } \\
\text { number }\end{array}$} & \multicolumn{2}{c}{ No. participants reporting } & \multicolumn{2}{c}{ Normalized subset results } \\
\cline { 5 - 6 } & All & Subset $^{\mathrm{b}}$ & & Range & Mean \pm \\
\hline 1 & 36 & 34 & $0.69-2.75$ & $1.29 \pm 0.47$ \\
2 & 39 & 39 & $0.72-2.94$ & $1.17 \pm 0.45$ \\
3 & 39 & 39 & $0.39-2.99$ & $0.97 \pm 0.49$ \\
4 & 39 & 36 & $0.33-2.68$ & $1.39 \pm 0.52$ \\
5 & 40 & 35 & $0.48-2.47$ & $1.19 \pm 0.40$ \\
6 & 32 & 29 & $0.00-2.44$ & $0.99 \pm 0.65$ \\
\hline
\end{tabular}

"Not all participants reported both neutron and gamma (i.e., total) dose equivalent.

Subset refers to reported data less than 3 times the reference value.

Reported total dose equivalent divided by reference value. 

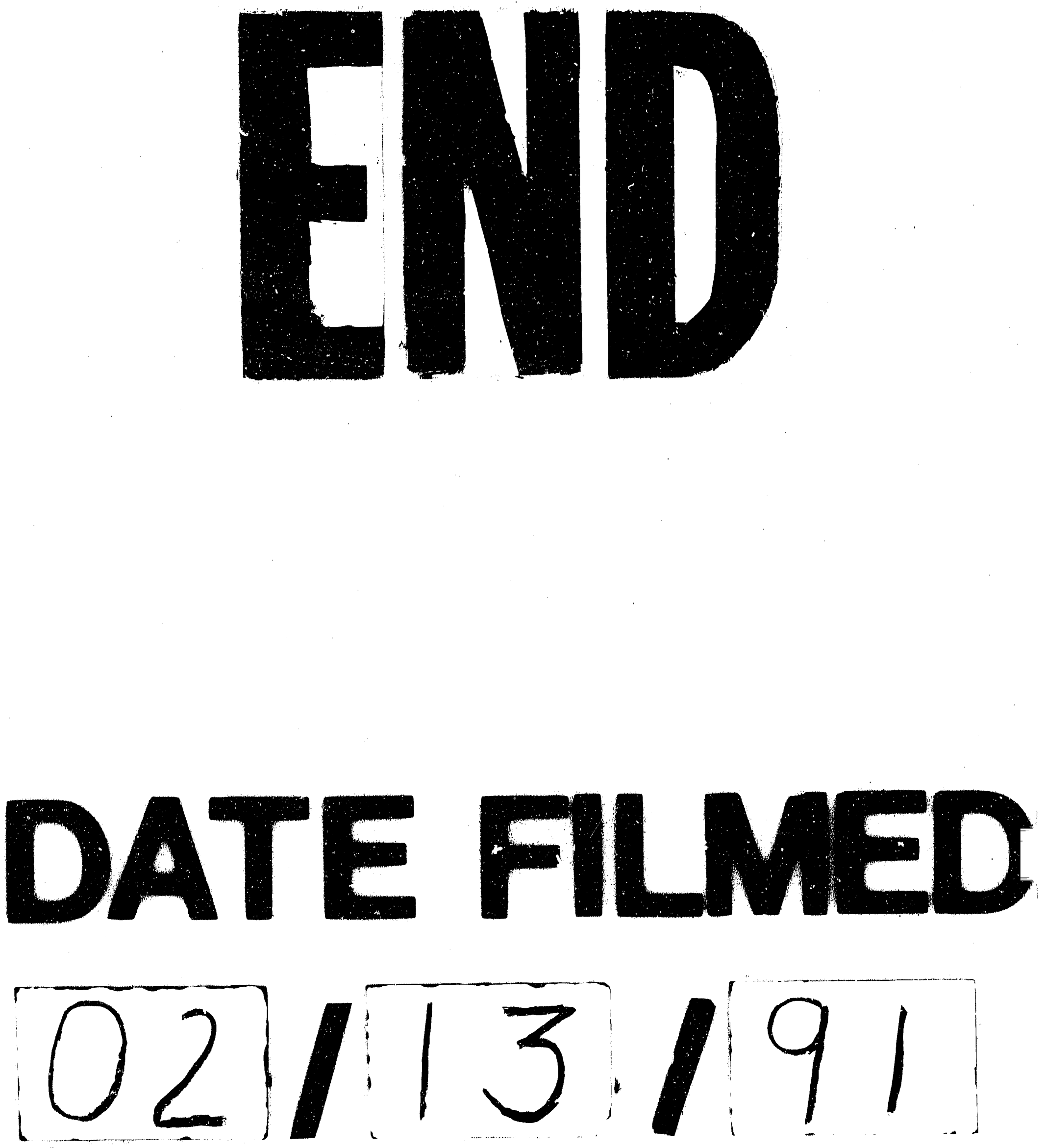
